\title{
Application of metal - organic frameworks
}

\section{Claudio Pettinari, ${ }^{a *}$ Fabio Marchetti, ${ }^{b}$ Nello Mosca, ${ }^{a}$ Giovanni Tosi ${ }^{a}$ and Andrei Drozdov}

\begin{abstract}
The burgeoning field of metal - organic frameworks or porous coordination polymers has received increasing interest in recent years. In the last decade these microporous materials have found several applications including storage and separation of gases, sensors, catalysis and functional materials. In order to better design new metal - organic frameworks and porous coordination polymers with specific functionalities a fundamental issue is to achieve a basic understanding of the relationship between molecular parameters and structures, preferred adsorption sites and properties by using using modern theoretical methods. The focus of this mini-review is a description of the potential and emerging applications of metal - organic frameworks.
\end{abstract}

(c) 2017 Society of Chemical Industry

Keywords: MOFs; PCP applications; gas storage and separation; sensors; luminescence; catalysis; drug delivery

\section{INTRODUCTION}

Metal - organic frameworks (MOFs) or porous coordination polymers (PCPs) are crystalline materials possessing highly ordered structures consisting of networks formed by single metal ions or metal clusters connected by multidentate organic groups acting as linkers. ${ }^{1-4}$ The term coordination polymers appeared in 1960 but remarkable progress in this field has been made mainly from 1995 when Yaghi and colleagues coined the term metal - organic frameworks (MOFs). ${ }^{5,6}$ The idea of molecular building blocks linked into predetermined structures using strong bonds created the conceptual and practical basis of a new research area, namely reticular chemistry. ${ }^{7}$ An incredible number of coordination polymers in which the assembly of molecular crystals is held together by hydrogen bonds or the metals are connected by multitopic organic components such as 4,4'-bipyridyl (4,4'-bpy) are being reported; however, MOFs are defined as compounds in which all the components are linked by strong covalent bonds., 8

The main MOF feature is porosity, which makes these organic-inorganic hybrid materials similar to zeolites. Some of them have record surface areas exceeding those in zeolites. The surface area of $1 \mathrm{~g}$ of some MOFs is comparable with a square of football field $(120 \times 53.33$ yards implies 6400 square yards or ca $5351 \mathrm{~m}^{2}$ ). ${ }^{10}$ An exceptional surface area (up to $6000 \mathrm{~m}^{2} \mathrm{~g}^{-1}$ ) makes it possible to take up voluminous amounts of such gases as hydrogen, methane and carbon dioxide, suggesting the use of MOFs for $\mathrm{H}_{2}$ storage ${ }^{11}$ at high density, a critical issue for $\mathrm{H}_{2}$-based clean energy technologies.

Small density, high surface area, tunable pore functionality and structural flexibility make them useful in a wide area of prospective applications, including not only gas storage but also liquid phase separation, heterogeneous catalysis, drug delivery, sensing, proton conductivity etc. (Fig. 1). ${ }^{12-14}$ Very recently MOFs have also been employed as an interesting platform to hierarchically organize light-harvesting antennae and catalytic centres to achieve solar energy conversion. ${ }^{15}$

MOFs have been employed in the research area of polymers through the construction of nanocomposites between MOFs and polymers to provide unprecedented material platforms which can accomplish many nanoscale functions including controlled polymerization, new polymer - MOF hybrid membranes, and stabilization of immiscible polymer blends using MOFs to give new materials with innovative features not achievable with individual components. ${ }^{16-19}$

Many synthesized MOFs, however, have relatively weak thermal and chemical stability compared to zeolites which restricts their use in large scale industrial applications. It is possible to classify MOFs on the basis of framework robustness. ${ }^{20}$ In the first generation MOFs the framework undergoes irreversible collapse once the guest molecules are removed. The second generation MOFs have stable and rigid frameworks characterized by permanent porosity that remains even after the guest molecules are removed. Finally, third generation MOFs possess flexible and dynamic frameworks which can change their channels or pores reversibly in response to an external stimulus (radiation, light, pressure etc).

\section{STRUCTURAL ASPECTS AND TOPOLOGY OF MOFS}

A coordination polymer is generally composed of metal atoms as connectors and organic groups as linkers (Fig. 2). ${ }^{21}$

The geometry and coordination environment depend strictly on the nature of the metal. In contrast to zeolites, which are built mainly from tetrahedral building blocks, MOFs can be formed

\footnotetext{
Correspondence to: C Pettinari, School of Pharmacy-chemistry section, University of Camerino, via S. Agostino 1, Camerino, 62032, Italy. E-mail: claudio.pettinari@unicam.it

a School of Pharmacy-chemistry section, University of Camerino, Camerino, Italy

b School of Science and Technology-chemistry section, University of Camerino, Camerino, Italy

c Lomonosov Moscow State University, Moscow, 119991, Russian Federation, Department of Chemistry, Moscow, Russian Federation
} 
Claudio Pettinari received an MSc degree in chemistry (1989) from the University of Camerino, Italy, where he has been full Professor since 2010. He is a winner of the Nasini Medal and the Bonati prize. In the last 4 years his interest has moved to new frontiers and emerging research fields such as those represented by metal-organic frameworks and porous coordination poly-

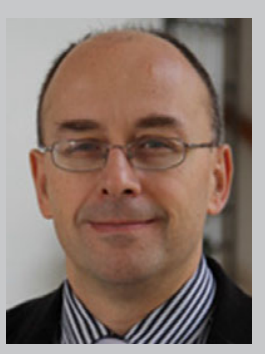
mers, mainly based on heterocyclic N-donor ligands, as perspective materials for gas sensors, luminescence, catalysis and biological activity.

Fabio Marchetti received an MSc degree in chemistry (1991) and a PhD in chemistry (1996) from the University of Camerino, Italy. Then he joined the University of Camerino as a researcher, and in 2011 he became full Professor of General and Inorganic Chemistry at the School of Science and Technology at the University of Camerino. Dr Marchetti's research programme focuses on outstanding challenges at the interface of inorganic and materials chemistry.

Nello Mosca obtained a masters degree at the University of Camerino in chemistry and advanced chemical methodologies and a masters degree at the Instituto Superior Técnico of Lisbon in chemistry. Currently he is a PhD student under the supervision of Professor Claudio Pettinari at the University of Camerino (Italy). His current research focuses on the synthesis and characterization of novel coordination polymers or metal-organic frameworks, based on $\mathrm{N}$ - or O-donor ligands and transition metals.

Giovanni Tosi graduated in Sciences and Technologies for the Environment and he is carrying out $\mathrm{PhD}$ research at the University of Camerino in partnership with COSMOB (the Italian Technological Centre) about VOC indoor pollution. He has experience in coordinating and developing $R \& D$ projects at national and international level.

Andrey Drozdov, PhD, Associate Professor, born in 1969. In 1991 he graduated from Moscow State University, and in 1994 he obtained a PhD in chemistry. His main scientific interests are coordination chemistry of rare earth elements with organic ligands, coordination polymers, luminescence and structural chemistry.
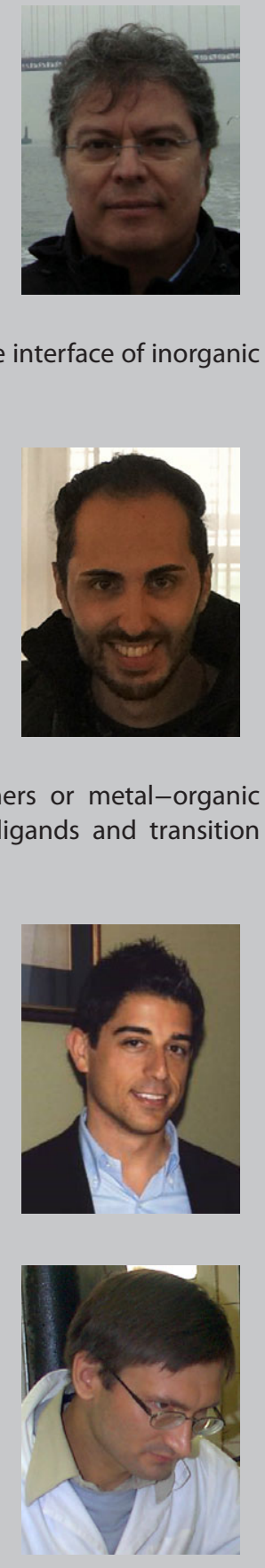

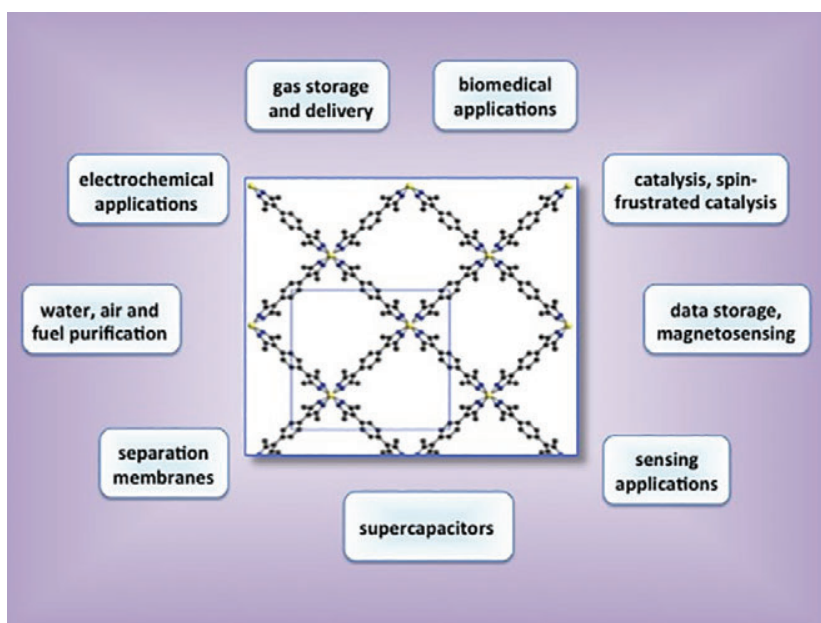

Figure 1. MOF and PCP applications.

from a wide variety of inorganic fragments. For a given shape of fragment, only a small number of high-symmetry topologies resulting in a stable network are possible. Accordingly, for a given shape it should be possible to prepare a series of compounds with the same preferred topology but differing only in the nature and size of the linkers - an isoreticular series. ${ }^{22}$ MOFs having the same topology are called isoreticular (IRMOFs). The rigidity of the framework depends on the linker employed and on the reactivity of the metal centre. Assemblies of these polyhedra are called secondary building units (SBUs). This term, first used to describe zeolite fragments, is now applied to identify building blocks forming MOFs. The structure of the framework depends strictly on the nature of the SBUs, while the porosity can be changed by altering the length of the linker.

An important class of 3D frameworks is based on zinc carboxylates, introduced by Yaghi et al., ${ }^{7,23}$ One of them is MOF-5, also known as IRMOF-1 (Fig. 3(a)). It is composed of tetrahedral $\mathrm{Zn}_{4} \mathrm{O}$ clusters linked in a cubic unit by terephthalate linkers. In this example an isoreticular series forms via the linkage of octahedral metal-containing SBUs by a variety of linear dicarboxylate groups acting as linkers. Upon changing the terephthalate linker with other bidentate linear groups a family of MOFs with similar morphology and cubic arrangement have been obtained called IRMOF-2, IRMOF-3 etc., or IRMOF- $n(n=1-7,8,10,12,14,16) .{ }^{24,25}$

Another well-known MOF family is based on a copper(II) square 'paddle-wheel' formed by $\mathrm{Cu}_{2}\left(\mathrm{CO}_{2}\right)_{4}$ units. One of them has the formula $\mathrm{Cu}_{3}(\mathrm{btc})_{2}$, where $\mathrm{H}_{3}$ btc is trimesic (1,3,5-benzenetricarbonic) acid. This MOF is also known as HKUST-1 (Fig. 3(b)) named from the first report about this species by the Hong Kong University of Science and Technology in 1999. ${ }^{26}$ Now it is commercially available as Basolite $C$ with a surface area of $1900 \mathrm{~m}^{2} \mathrm{~g}^{-1}$. Using the nonlinear linker derived from the tritopic carboxylic acid 1,3,5-tris (4'-carboxyphenyl)benzene $\left(\mathrm{H}_{3} \mathrm{btb}\right)$, a MOF called MOF-177 has been obtained. ${ }^{27-29}$ It is a material with one of the largest known surface areas up to now. A facile method has very recently been reported to yield MOF- 5 with HKUST- 1 embedded into it, producing an HKUST-1/MOF-5 structure suitable for molecular encapsulation by trapping dye molecules in HKUST-1 particles and embedding them in MOF- 5 crystals. ${ }^{30}$

UiO-66 is a zirconium-cluster-based MOF consisting of $\mathrm{Zr}_{6} \mathrm{O}_{4}(\mathrm{OH})_{4}$ octahedra (Fig. 3(c)) connected to adjacent octahedra through a 1,4-benzenedicarboxylate (BDC) linker in a highly packed face-centred cubic structure. ${ }^{31-33}$ The additional stability 


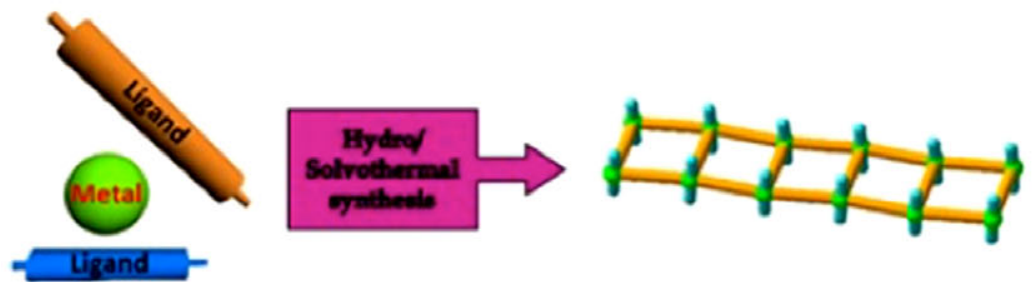

1D

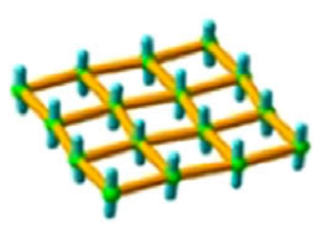

2D

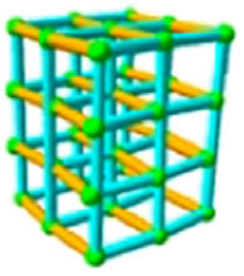

$3 \mathrm{D}$

Figure 2. Synthesis of PCPs by using metal atoms as connectors and organic linkers.

(a)

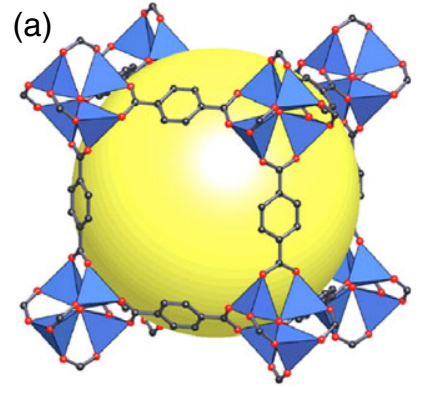

(b)

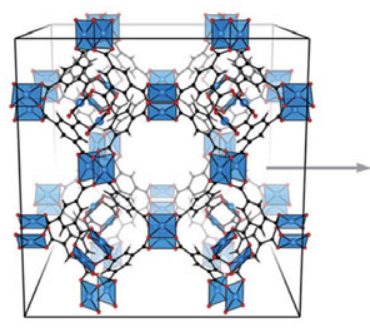

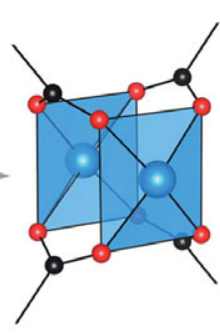

(c)

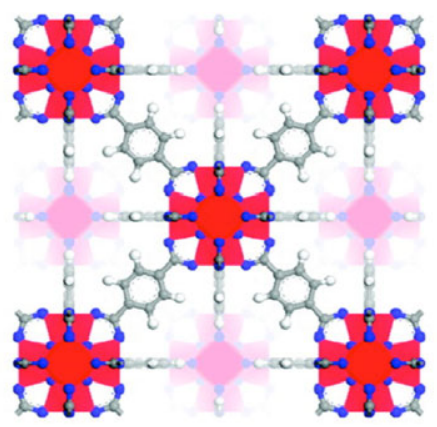

Figure 3. (a) MOF-5 structure (reproduced with permission from ref. 3). (b) HKUST structure ${ }^{26}$ (reproduced with permission from Fig. 1 in Hendon $\mathrm{CH}$, Walsh A, Chem Sci 6: 3674 (2015), ${ }^{34}$ copyright (2015) Royal Society of Chemistry). (c) UiO-66 structure (reproduced with permission from ref. 32).

of this compound is due to $\mathrm{Zr}-\mathrm{O}$ bonds formed between the cluster and carboxylate ligands and the ability of the inner $\mathrm{Zr}_{6}$ cluster to rearrange reversibly upon removal or addition of bridging $\mathrm{OH}$ groups, without any changes in the connecting carboxylates.

Another example is represented by mixed-linker systems containing more than one type of bridging ligand, such as MOF-205 (Fig. 4), $\mathrm{Zn}_{4} \mathrm{O}(\mathrm{BTB})_{4 / 3}$ (NDC) (BTB $\equiv$ benzene-1,3,5-tribenzoate and NDC $\equiv$ naphthalene-3,7-dicarboxylate). MOF-205, containing an extended organic linker, demonstrated the utility of isoreticular expansion for the prediction of both structure and porosity when the parent MOF is well known. ${ }^{34,35}$

The MIL series (MIL stands for Materials Institute Lavoisier) associated with Férey and colleagues is based mainly on carboxylate ligands (such as 1,3,5-benzene tricarboxylate, terephthalate, isophthalate etc.) and trivalent metal ions of $\mathrm{V}, \mathrm{Cr}, \mathrm{Fe}, \mathrm{Al}, \mathrm{Ga}$ and In and also lanthanides, ${ }^{36-39}$ but also studies with metal ions in different oxidation states have been reported, such as Ti(IV). ${ }^{40}$ MIL-100 and MIL-101 (Fig. 5) show exceptional porosity and an augmented mobil thirty-nine zeotype structure. ${ }^{41-45}$

The ZIF series is based on zeolitic imidazolate frameworks obtained by copolymerization of zinc and cobalt ions with imidazole-type linkers. The ZIF structures consist of nets of seven different aluminosilicate zeolites where the tetrahedral Si/Al clusters are replaced by $\mathrm{Zn}$ or $\mathrm{Co}$ and the bridging $\mathrm{O}$ by the bridging imidazolates. ${ }^{46}$

The structure of MOFs can also be temperature and pressure dependent. For example the unit cell volume of $\mathrm{Zn}\left(\mathrm{HO}_{3} \mathrm{PC}_{4} \mathrm{H}_{8} \mathrm{PO}_{3} \mathrm{H}\right) \cdot 2 \mathrm{H}_{2} \mathrm{O}$ (ZAG-4) decreases by over $27 \%$ under high pressures $(0-9.9 \mathrm{GPa})$, the unit cell parameters reverting to their original values when the pressure is removed. This kind of MOF is close to piezofunctional solid-state materials that can be applied as highly sensitive pressure sensors or pressure switches. ${ }^{47}$ In some MOFs showing small energy differences between two different particular network topologies, a simple change of solvent can cause the topological change. ${ }^{48}$
$\mathrm{Zn}_{2}(\text { ATRZ) })_{2}$ SBUs (ATRZ $\equiv 3$-amino-1,2,4-triazole) self-organize in a framework by bridging dicarboxylates. The resulting pillar-layered structure pattern remains unchanged for different dicarboxylates used. ${ }^{49}$

In some cases different structural patterns for MOFs, deriving from analogous combinations of metals and linkers, make interpenetration possible, as porous species tend to minimize the energy via optimal filling of void space. ${ }^{50}$

To predict the useful properties and reactivity of MOFs, quantum chemical computational methods have been developed and applied. ${ }^{51-53}$

\section{SYNTHESIS OF MOFS}

At first MOFs were prepared by diffusion techniques, in which solutions containing metal salts were slowly diffused into solutions containing organic ligands as potential linkers (e.g. 4,4'-bpy, bridging organic carboxylic acids) and weak bases (triethylamine). This approach, very time-consuming, unfortunally gave low yields. ${ }^{54,55}$ In a second period the method was supplemented by solvothermal methods: metals salts and organic linkers, poorly soluble, were electrically heated in water or in solvent (ethanol, $\mathrm{N}, \mathrm{N}$-dimethylformamide (DMF)) at high temperature for a time up to several days. This synthetic method has been commercialized by BASF and other companies, producing MOFs in large quantities., ${ }^{2,56}$ The use of DMF or $\mathrm{N}, \mathrm{N}$-diethylformamide (DEF) excludes the addition of base, as these compounds undergo decomposition at high temperatures to slowly generate an amine base that deprotonates the organic linker and generates the metal-organic clusters. This synthesis generally gives a crystalline product. Raising the temperature or extending the reaction time results in reduction of the surface area. The solvent used enters the porous structure of the MOF, so an important procedure is the extraction of the solvent from the pores. For this the crystals are treated with a low boiling weakly coordinating 
(a)

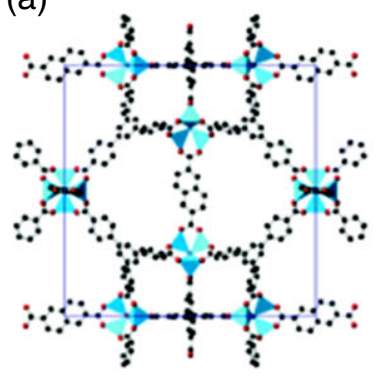

(b)

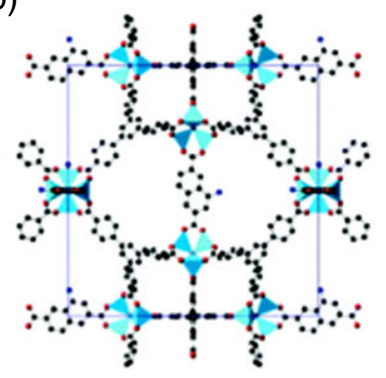

(c)

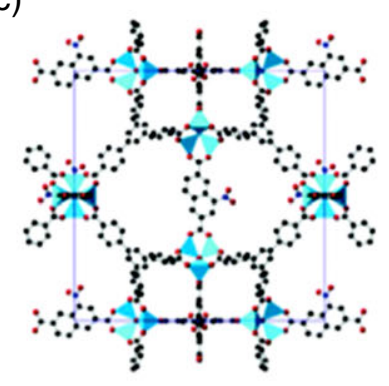

(d)

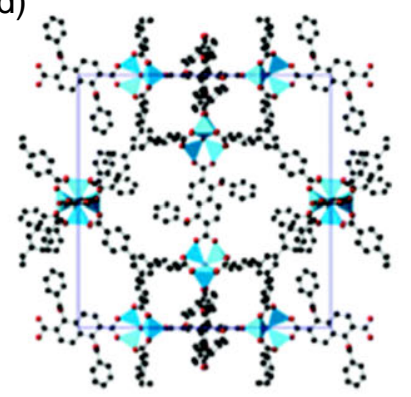

Figure 4. Unit-cell packing diagrams for the ordered model structures of (a) MOF-205, (b) MOF-205-NH 2 , (c) MOF-205-NO 2 and (d) MOF-205-OBn are displayed with $\mathrm{Zn}$ atoms as polyhedra and $\mathrm{C}, \mathrm{N}$ and $\mathrm{O}$ atoms as balls. Hydrogen atoms are not shown for simplicity (reproduced with permission from Fig. 1 in ref. 34, copyright (2014) Royal Society of Chemistry).
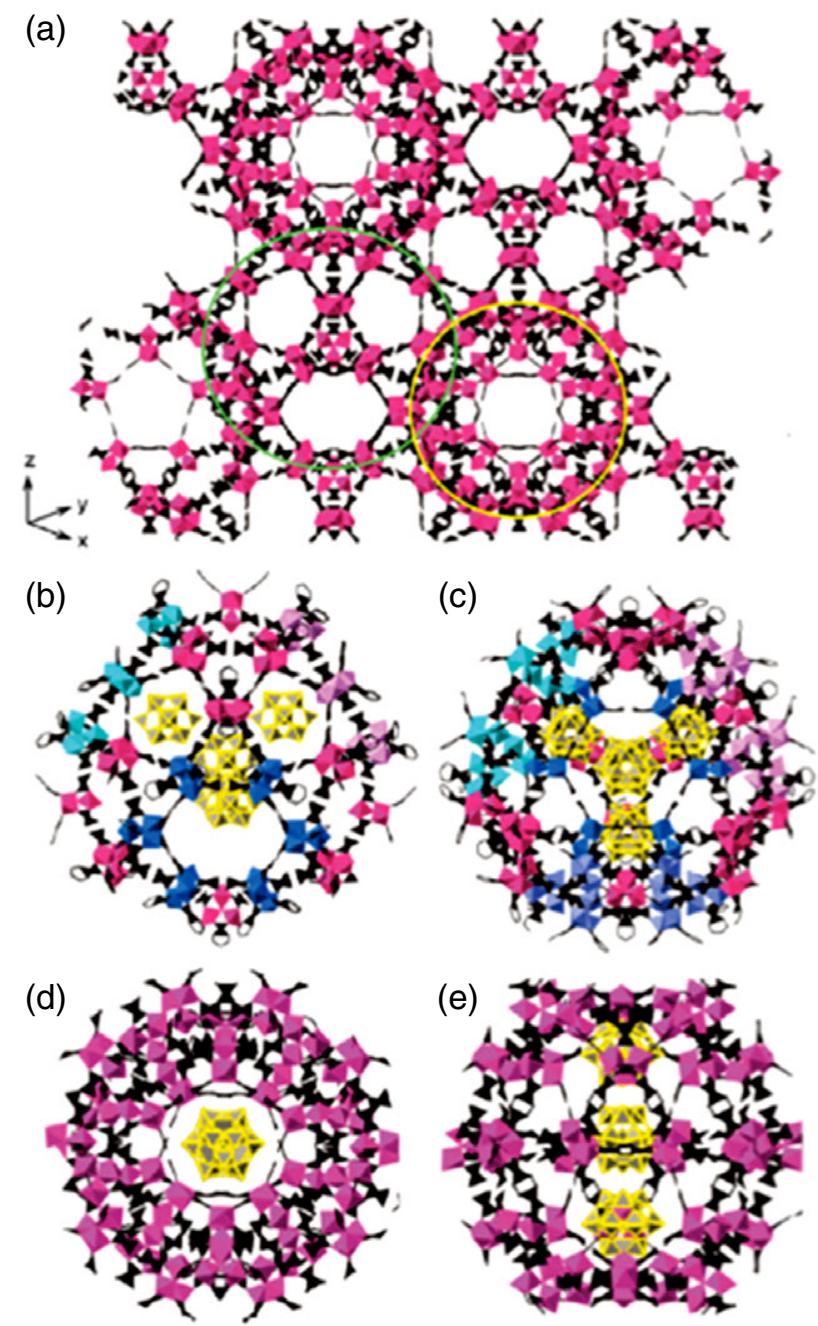

Figure 5. Proposed crystal structure of (a) MIL-101 and (b) - (e) MIL-101/PTA (PTA $\equiv$ phosphotungstic acid) composites. (a) MIL-101 crystal structure with the boundary of the large cage highlighted in green and that of the small cage highlighted in yellow (reproduced with permission from Fig. 7 in ref. 45, copyright (2012) American Chemical Society).

solvent such as chloroform and then dried in vacuo to extract the solvent. The final products are generally air and moisture sensitive and should be treated carefully. The synthesis of MOFs in water at room temperature has also been developed in which salts have been employed as linker sources. ${ }^{57}$ Another synthetic way to make MOFs is mechanochemical solid-state grinding without solvents. In some cases liquid-assisted grinding (synthesis in the presence of a small amount of solvent) can also be employed. ${ }^{58-60}$ In this method a mixture of organic linker and metal salt is ground together in a mechanical ball. The increase of the surface energy of the system leads to an increase of interaction ability that results in MOF formation. The products obtained by mechanochemical syntheses exhibit a high surface area. Sometimes small amounts of accessory salts facilitate the building of the framework; thus metal nitrates induce the formation of MOFs with a tetragonal structure, while sulfates induce a hexagonal one. ${ }^{61}$ Sonochemical syntheses are alternative routes to the solution synthesis of MOFs. ${ }^{62}$ This method produces high-quality crystals in high yield. The longer the synthesis time is, the larger are the crystals formed. ${ }^{63}$ Microwave-assisted solvothermal syntheses have been successfully applied to different types of MOFs. This process, involving heating with microwaves for a short period, affords nanosized crystals. ${ }^{64,65}$ Sometimes also the addition of $\mathrm{HCl}$ to the reaction mixture seems to increase porosity and decrease the reaction time. ${ }^{66}$

Among the recent methods developed for MOF production are electrochemical techniques characterized by several advantages such as mild synthesis conditions and short reaction times. ${ }^{67}$ This method consists in providing the metal ion by anodic dissolution in mixtures containing organic linkers and electrolytes. ${ }^{68}$ The porous nature of MOFs makes possible gas-phase loading with volatile organometallic compounds that results in the inclusion inside of single metal atoms or metal nanoparticles. ${ }^{69}$ Some synthetic routes, including nanoparticle formation in MOFs by decomposition of incorporated precursors or a templated synthesis approach, have been proposed. These systems could find application in hydrogen storage and heterogeneous catalysis. ${ }^{70}$ Post-synthetic modifications of previously reported MOFs can be an alternative method ${ }^{71}$ such as for example $\mathrm{N}_{3}$-decorated $\mathrm{Zn}_{4} \mathrm{O}\left(\mathrm{N}_{3} \mathrm{tpa}\right)(\mathrm{btb})_{4 / 3}\left(\mathrm{~N}_{3} \mathrm{tpa}^{2-} \equiv 2\right.$-azidoterephthalate; $\mathrm{btb}^{3-} \equiv 4$, $4^{\prime}, 4^{\prime \prime}$-benzene-1,3,5-triyl-tribenzoate) that has been transformed through a Cu-mediated acetylene coupling in a single step with a complete azido $\rightarrow$ triazole conversion. ${ }^{72}$

\section{APPLICATIONS: GAS STORAGE AND DELIVERY}

The main application described in the literature for MOFs is gas storage due to their exceptional surface areas. ${ }^{73-76}$ Clean energy applications of MOFs (hydrogen and methane storage, $\mathrm{CO}_{2}$ capture) are reviewed by $\mathrm{Ma}$ and $\mathrm{Zhou}^{77}$ The great champions MOF-177 (promising material for gas separation and storage at 


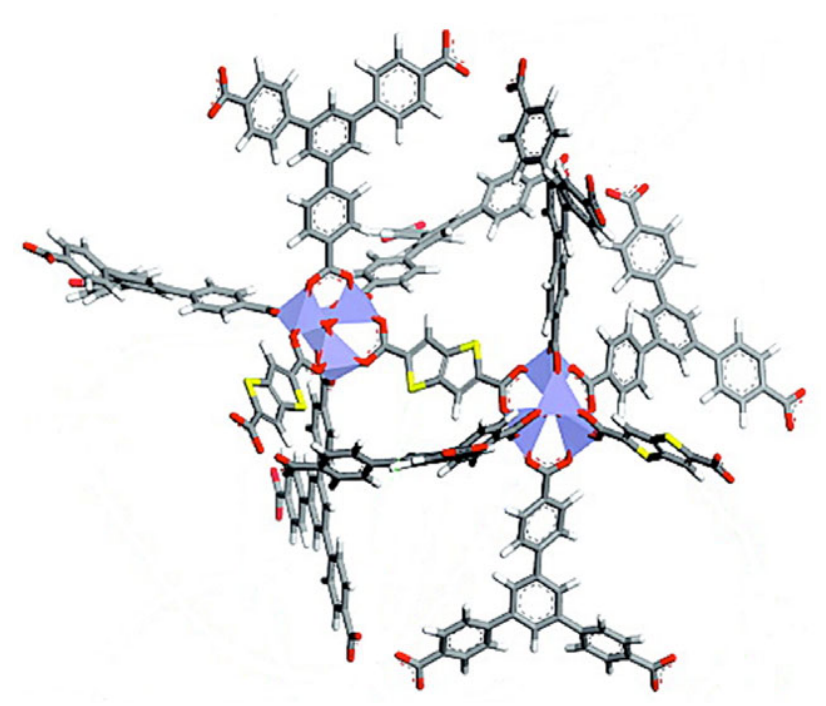

Figure 6. Structure of UMCM-2: two $\mathrm{Zn}_{4} \mathrm{O}$ clusters coordinated to three $T_{2} D C$ (thieno(3,2-b)thiophene-2,5-dicarboxylate) and eight BTB $\left(\mathrm{H}_{2} \mathrm{BTB} \equiv 1,3,5\right.$-tris(4-carboxylphenyl)benzene) linkers (adapted with permission from Fig. 1(a) in ref. 80, copyright (2009) American Chemical Society).

room temperature ${ }^{78}$ ) and MIL-101 have a surface area of 5640 $\mathrm{m}^{2} \mathrm{~g}^{-1}$ and $5900 \mathrm{~m}^{2} \mathrm{~g}^{-1}$, respectively; also the current record for surface area is held by UMCM-2 (UMCM- $2 \equiv \mathrm{Zn}_{4} \mathrm{O}\left(\mathrm{T}^{2} \mathrm{DC}\right)(\mathrm{BTB})_{4 / 3}$, where $\mathrm{H}_{2} \mathrm{~T}^{2} \mathrm{DC}$ is thieno[3,2-b] thiophene-2,5-dicarboxylic acid and $\mathrm{H}_{3} \mathrm{BTB}$ is 1,3,5-tris(4-carboxyphenyl)benzene; UMCM stands for University of Michigan Crystalline Material, Fig. 6) which presents a surface area of over $6000 \mathrm{~m}^{2} \mathrm{~g}^{-1}$. By varying the composition of both SBUs and linkers it is possible to modify the adsorbent capability of the material. ${ }^{79}$

MOFs are ideal materials for hydrogen storage at low temperatures. ${ }^{81}$ The most promising are MOFs with high hydrogen storage densities exceeding $10 \mathrm{wt} \%$ and $58 \mathrm{~g} \mathrm{~L}^{-1}(77 \mathrm{~K})$. The final target is to reach $7.5 \%$ of $\mathrm{H}_{2}$ by mass, i.e. $70 \mathrm{~g} \mathrm{~L}^{-1}$. The screening of MOFs from the Cambridge structural database allowed compounds to be chosen with high theoretical capacities and revealed that the relationship between gravimetric and volumetric $\mathrm{H}_{2}$ density is not linear but has a maximum for surface areas of 3100-4800 m² $\mathrm{g}^{-1} .82$ Adsorption measurements of $\mathrm{CH}_{4}$ carried out with $3 \mathrm{D}\left[\mathrm{Cu}\left(\mu-\mathrm{SiF}_{6}\right)\left(4,4^{\prime}-\mathrm{bpy}\right)_{2}\right] .8 \mathrm{H}_{2} \mathrm{O}$ suggested that above 5 bar pressure this PCP can take up more methane than a zeolite, showing the highest methane adsorption capacity of all zeolites. ${ }^{83}$ $\mathrm{Cu}\left(\mu-\mathrm{SiF}_{6}\right)\left(4,4^{\prime}-\mathrm{bpy}\right)_{2}$ at $298 \mathrm{~K}$ and 1 atm shows a relative uptake of $\mathrm{CO}_{2}$ over $\mathrm{CH}_{4}$ of $\mathrm{ca} 10: 1$, the highest value to date found experimentally in a PCP without open metal sites. ${ }^{84}$ The $\mathrm{CH}_{4}$ uptake properties of six different MOFs have been widely investigated. HKUST-1 shows a greater room-temperature methane uptake with respect to the values reported to date (230 cc (STP)/cc at 35 bar and $270 \mathrm{cc}$ (STP)/cc at 65 bar). These values meet the volumetric target indicated by the US Department of Energy. ${ }^{85}$ Analogously, an Al MOF with square-octahedron topology, reported by Eddaoudi and co-workers, addresses the challenging Department of Energy dual target of $0.5 \mathrm{~g}$ (gravimetric) and $264 \mathrm{~cm}^{3}$ (STP) $/ \mathrm{cm}^{3}$ (volumetric) $\mathrm{CH}_{4}$ storage. ${ }^{86}$ The adsorption of pure $\mathrm{N}_{2} / \mathrm{H}_{2} / \mathrm{CH}_{4} / \mathrm{CO}_{2}$ along with the adsorption and separation of mixtures thereof in MOFs were also investigated using hybrid methods of computer simulation and adsorption theory. ${ }^{87}$ It has been very recently reported that surface modification of MOFs can offer control over fundamental applications in gas adsorption and delivery. ${ }^{88} \mathrm{It}$ is also well known that the gas storage performance strongly depends on the synthetic method and scale production employed. ${ }^{89}$ Two $\mathrm{Zn}$ and Cu tetramethyl-bipyrazole-based MOFs have been structurally characterized and their electronic properties compared. Their reactivity towards $\mathrm{H}_{2}$ and $\mathrm{CO}_{2}$ molecules was investigated also by $a b$ initio calculations performed on periodic models with the B3LYP hybrid and an empirical long-range dispersion correction..$^{90,91} \mathrm{~K}$-means clustering and archetypal analysis was applied to identify the most relevant nanoporous structures in a large library of ca 82000 virtual MOFs. In the same work also quantitative structure-property relationship models of the theoretical $\mathrm{CO}_{2}$ and $\mathrm{N}_{2}$ uptake capacities were developed. ${ }^{92}$

\section{MOFS FOR BIOMEDICAL APPLICATIONS}

MOFs are potential efficient drug delivery materials as their properties can be modified by adjusting the functional groups of the frameworks and by finely tuning the pore size. ${ }^{93}$ The MIL family, which can be obtained from trivalent metal centres and bridging carboxylates, is a promising class of MOFs in drug delivery as they exhibit large pore sizes $(25-24 \AA)$ and relevant surface areas $\left(3100-5900 \mathrm{~m}^{2} \mathrm{~g}^{-1}\right)$. MIL-100 and MIL-101 possessing a well-defined structure and ordered porosity have been investigated for the delivery of ibruprofen. Some quantum mechanical calculations were performed to examine the interaction of ibuprofen with MIL-53(Fe): a strong binding energy, comparable to that reported for ibuprofen - zeolite interaction, was found due to the strong interaction between the carboxylic oxygen of ibuprofen and the hydroxyl group of MIL-53(Fe). ${ }^{94}$ Computational studies have also been carried out on the energetics and dynamics of ibruprofen in MIL-101 and UMCM-1 (UMCM-1 $\equiv \mathrm{Zn}_{4} \mathrm{O}(\mathrm{BDC})(\mathrm{BTB})_{4 / 3}$, where $\mathrm{H}_{2} \mathrm{BDC}$ is terephthalic acid). ${ }^{95,96}$

Several MOFs have been prepared possessing hydrophilic pores able to carry either positive or negative charges, useful to encapsulate drugs having opposite charge with respect to the MOFs. ${ }^{97,98}$ MOFs can also be used as materials able to incorporate biomolecules and biocompatible metal cations: they can, in fact, incorporate biomolecules as linkers or bioactive metals as nodes in the framework useful for imaging applications. ${ }^{99}$ Nanoparticles of $\mathrm{Zr}_{6} \mathrm{O}_{4} \mathrm{OH}_{4}\left(\mathrm{C}_{8} \mathrm{H}_{3} \mathrm{O}_{4}-\mathrm{N}_{3}\right)_{6}\left(\mathrm{UiO}-66-\mathrm{N}_{3}\right)$ were covalently functionalized with oligonucleotide, the structure of the MOF being preserved. The colloidal stability and the cellular transfection capabilities of the functionalized MOF were investigated, large differences being found with respect to the unfunctionalized MOF nanoparticles. ${ }^{100}$

MOF size is very important for their application as drug delivery vehicles. However, MOF use is sometimes difficult as they are not appropriate for systemic circulation: non-toxic iron(III)-based MOFs characterized by engineered cores and surfaces demonstrated their efficiency as nanocarriers for the delivery of antitumoral and retroviral drugs such as doxorubicin, azidothymidine and busulfan. ${ }^{101}$ A series of biocompatible MOFs bearing different topologies has been investigated for the encapsulation and release of the liporeductor cosmetic caffeine. ${ }^{102}$ Highly degradable nanoparticles based on nanoscale coordination polymers containing Pt exhibit high anticancer efficiency in vitro toward the human colon carcinoma cell line (HT-29). ${ }^{103}$ Post-synthetic modification of porous MOFs is an important strategy to introduce amine groups in the MOFs. The amine groups serve for loading optical imaging contrast agents such 
as 1,3,5,7-tetramethyl-4,4-difluoro-8-bromomethyl-4-bora-3a,4adiaza-indacene. ${ }^{104}$ Some studies have been performed to measure the gravimetric adsorption of NO by HKUST-1, NO being a fundamental gas involved in biological processes within the neuronal and vascular systems. ${ }^{105}$ Diazeniumdiolate has also been incorporated in MOFs through a post-synthetic modification yielding species able to release NO. ${ }^{106}$ Nanorods and nanoplates were prepared by using an emulsion of $\mathrm{GdCl}_{3}$ and bis (methylammonium)benzene-1,4-dicarboxylate in a system containing cetyltrimethylammoniumbromide/isooctane/1-hexanol/ water. These systems, due to the presence of $\mathrm{Gd}^{3+}$ centres, have been studied as contrast agents for magnetic resonance imaging. ${ }^{107}$

The antibacterial action of 4,4'-bipyrazolyl-based silver(I) coordination polymers embedded in polyethylene discs has been evaluated. Complete reduction of three bacterial strains was achieved in $24 \mathrm{~h}$, the reduction of Staphylococcus aureus reaching ca $90 \%$ in only 2 h. ${ }^{108}$ The outer surface of porous nano-MOFs can be functionalized by coating cyclodextrin molecules bearing iron-complexing groups such as phosphates on the nano-MOF surface. It has been observed that the coating does not affect the MOF porosity, adsorption and release capability. For this reason the coating has also been functionalized with different targeting groups in order to interact with specific receptors or with polyethylene glycol chains to escape the immune system. ${ }^{109}$ MOFs can be assembled also in microcapsules by using cell walls (CW) from natural biomaterials as non-toxic supports. The very stable MOF/CW microcapsules can favour the slow size-selective release of small molecules. ${ }^{110}$

\section{CATALYTIC APPLICATIONS OF MOFS}

MOFs can be considered an alternative approach to heterogeneous catalysts emulating the catalytic properties of homogeneous complexes. ${ }^{111}$ An appropriate design and a careful choice of organic linkers could allow the preparation of MOFs characterized by a local structure analogous to that found, for example, in any given metal coordination compounds possessing the required catalytic activity. In addition it is also possible to rationally design the environment with a high degree of precision. MOFs can act as spectator species where the catalytic reaction takes place or can be the active site, able to stabilize the transition state and orient the molecules. In some cases the catalytic activity of MOFs is due to the presence of unsaturated metal centres or catalytic species existing in the pores or inherent sites in the MOFs.

A detailed overview of the possible application in catalysis can be found in a review by Kitagawa et al. ${ }^{112}$ The versatility of MOFs as heterogeneous catalysts for efficient catalytic organic transformation has been reviewed more recently by Gascon et al. ${ }^{113}$ and Verpoort and colleagues. ${ }^{114}$ Selected examples of MOF-catalysed reactions are listed in Table 1. Some interesting examples of MOF catalysis are constituted by $\left[\mathrm{Cu}(2 \text {-pymo })_{2}\right]^{115,126}$ and $\left[\mathrm{Co}(\mathrm{PhIM})_{2}\right]^{44,115} \quad$ (2-pymo $\equiv 2$-hydroxypyrimidinolate; $\mathrm{PhIM} \equiv$ phenylimidazolate) which have been successfully used for the aerobic oxidation of tetralin, yielding $\alpha$-tetralone $(T=0)$ as the main product, where the significant differences between the two MOFs are related to the different catalytic behaviours of their central metal ions. MOFs are also rapidly replacing the classical approaches for acidic catalysis: MOF-199 $\left(\mathrm{Cu}_{3}(1,3,5 \text {-benzenetricarboxylate })_{2}\right)$ is a recyclable very efficient heterogeneous acid catalyst usable in the
Table 1. Selected examples of MOF-catalysed reactions

\begin{tabular}{|c|c|c|}
\hline MOF & Catalysed reaction & Reference \\
\hline $\mathrm{Cu}(2-\mathrm{pymo})_{2}^{\mathrm{a}}$ & Aerobic olefin oxidation & 114 \\
\hline $\mathrm{Co}(\mathrm{sal})\left(\mathrm{H}_{2} \mathrm{O}\right)(\mathrm{py})_{3}{ }^{\mathrm{b}}$ & Olefin epoxidation & 115 \\
\hline$\left[\mathrm{Cd}(\mathrm{bpy})_{2}\right]\left(\mathrm{NO}_{3}\right)_{2}{ }^{\mathrm{C}}$ & Cyanosilylation of aldehydes & 116 \\
\hline MIL-100(Fe) & Friedel - Crafts benzylation & 117 \\
\hline $\mathrm{ZIF}-8$ & Cycloaddition of $\mathrm{CO}$ and epoxides & 118 \\
\hline UiO-66 & Cyclization of citronella & 119 \\
\hline $\mathrm{Co}(\mathrm{PBP})$ & Olefin oxidation & 120 \\
\hline$\left[\mathrm{Ag}_{3}(\mathrm{tpha})_{2}\right] \mathrm{BF}_{4}{ }^{\mathrm{d}}$ & 1,3-dipolar cycloaddition & 121 \\
\hline MIL-101(Cr) & $\begin{array}{l}\text { Heck coupling/Knoevenagel } \\
\text { condensation }\end{array}$ & 122 \\
\hline $\mathrm{Cu}_{3}(\mathrm{btc})_{2}^{\mathrm{e}}$ & Isomerization & 123 \\
\hline $\mathrm{Zn}_{4} \mathrm{O}(\mathrm{bdc})_{3}{ }^{\mathrm{f}}$ & Friedel - Crafts alkylation & 124 \\
\hline $\mathrm{Pd}(2-\text { pymo })_{2}$ & Alcohol oxidation & 114 \\
\hline
\end{tabular}

a 2-pymo $\equiv 2$-hydroxypyrimidinolate; ${ }^{b}$ sal $\equiv$ salicylaldehyde; ${ }^{\mathrm{C} P B P} \equiv 1$, 4-bis[(3,5-dimethyl)pyrazol-4-yl]; d tpha $\equiv$ tris(4-(1-(2-pyridin-2ylhydra zono)ethyl)-phenyl)amine; ${ }^{\mathrm{e}} \mathrm{btc} \equiv$ benzene-1,3,5-tricarboxylate; ${ }^{\mathrm{f}} \mathrm{bdc}$ $\equiv$ 1,4-benzenedicarboxylate.

aza-Michael reaction of benzylamine with ethylacrylate to yield 2-(benzyl-amino)acetate. ${ }^{127}$

The previously described MIL-101, containing Pd nanoparticles, has been investigated as a bifunctional Lewis acid/hydrogenation catalyst in the one-pot synthesis of methylisobutyl ketone from acetone and $\mathrm{H}_{2}{ }^{128}$ MOF-5 has been probed for Friedel - Crafts benzylation of toluene with benzyl bromide as a heterogeneous acid catalyst. ${ }^{129}$ MIL-47 and MOF-48 (vanadium-containing MOFs) have been employed as catalysts in methane conversion to acetic acid. ${ }^{130}$ Several MOFs and PCPs have also been studied as catalysts for the oxidation of organic species in the presence of oxidants such as tert-butylhydroperoxide, $\mathrm{H}_{2} \mathrm{O}_{2}$ and $\mathrm{O}_{2}$.

Coordination Polymers (CPs), built up with either rigid or flexible bis(pyrazole)-based tectons, were tested as catalysts in the microwave-assisted solvent-free peroxidative oxidation of alcohols by $t-\mathrm{BuOOH}$ and in the peroxidative oxidation of cyclohexane to cyclohexanol and cyclohexanone by $\mathrm{H}_{2} \mathrm{O}_{2}$ in acetonitrile. CPs bearing rigid spacers possessing higher specific surface areas are more active than the corresponding CPs with flexible spacers. ${ }^{131}$ An interesting example, outlining the importance of having empty or filled channels in MOFs, is represented by the use of $\ln (\mathrm{OH}) \mathrm{L}$ and $\ln (\mathrm{OH}) \mathrm{L} . x$ (pyridine) $\left(\mathrm{L} \equiv 4,4^{\prime}\right.$ (hexafluoroisopropylidene)bisbenzoic acid) for the acetalization of aldehydes. When the channels are empty, as in $\ln (\mathrm{OH}) \mathrm{L}$, the catalytic activity increases. ${ }^{132}$

Catalysis can take place also at the organic linker: e.g. the introduction of basic functionalities such as amino and amide groups can yield very active solid basic catalysts. For example the role played by linkers containing the electron-releasing $\mathrm{NH}_{2}$ group or the electron-withdrawing $\mathrm{NO}_{2}$ group in $\mathrm{Zr}_{6} \mathrm{O}_{4}(\mathrm{OH})_{4}\left(\mathrm{NH}_{2}\right.$-bdc) and $\mathrm{Zr}_{6} \mathrm{O}_{4}(\mathrm{OH})_{4}\left(\mathrm{NO}_{2} \text {-bdc }\right)_{6}$ has been investigated in the acetalization of benzaldehyde with $\mathrm{MeOH} .{ }^{133}$ Also homochiral MOFs have been reported, one example being $\left[\mathrm{Cd}_{3} \mathrm{~L}_{4}\left(\mathrm{NO}_{3}\right)_{6}\right] .7 \mathrm{MeOH} .5 \mathrm{H}_{2} \mathrm{O}$ $\left(\mathrm{L} \equiv(\mathrm{R})-6,6^{\prime}\right.$-dichloro-2,2'-dihydroxo-1,1-binaphthyl-4,4'-bipyri dine) that, upon treatment with excess $\mathrm{Ti}\left(\mathrm{O}^{i} \mathrm{Pr}\right)_{4}$, gave an active catalyst for the addition of $\mathrm{Et}_{2} \mathrm{Zn}$ to aromatic aldehydes affording chiral secondary alcohols with high selectivities. ${ }^{134}$

Post-synthetic modifications can be employed to implement the catalytic function at both inorganic and organic moieties. An 


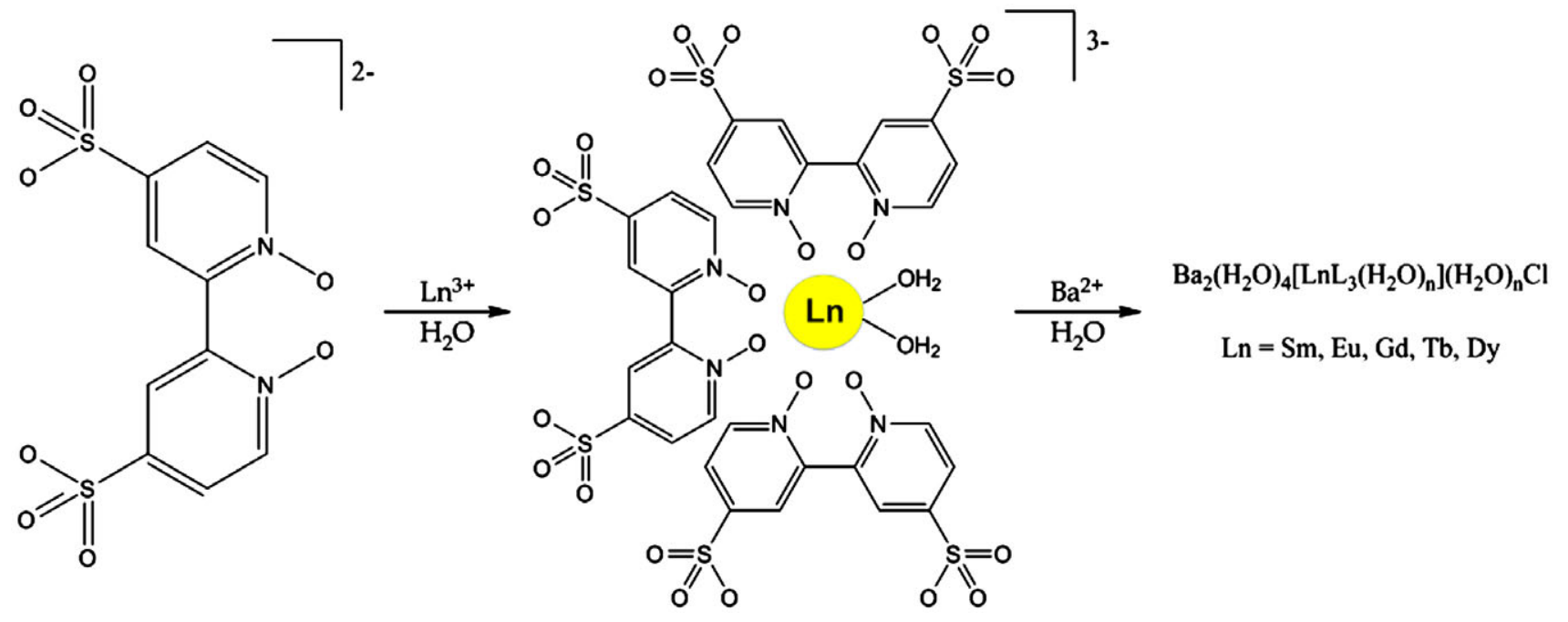

Figure 7. Building block approach to microporous Ln solids.

amine-containing MOF has been modified with two different cyclic anhydrides. Upon their incorporation into the MOF structure they act as chelating agents for metals such as copper or iron. These metal sites are catalytic, a carbon - carbon bond formation reaction occurring with the iron-containing MOF, with good efficiency and total recovery of the MOF. ${ }^{135}$ In addition the pores can be the place where a catalytic species is encapsulated. Arenetricarbonyl metal complexes, built within Zr-based MOFs, act as highly active and selective catalysts for epoxidation of cyclooctene, the catalytic activity being enhanced by increasing the pore sizes of the Zr-based MOFs. ${ }^{136}$ A number of MOFs have great affinity for $\mathrm{CO}_{2}$; their porosity and structure tunability make them prospective catalysts for the formation of organic carbonates by $\mathrm{CO}_{2}$ and epoxides through cycloaddition reactions. ${ }^{137}$ MOF-supported $\mathrm{Mo}(\mathrm{VI})$ complexes containing $\mathrm{N}, \mathrm{O}$-chelating ligand, prepared via dative and covalent-dative post-synthetic modifications, have been reported as active catalysts toward both epoxide selectivity and full re-usability for alkene epoxidation by tert-butylhydroperoxide. ${ }^{138}$ Chiral porous MOFs containing enantiopure-functionalized dipyridyl bridging ligands also showed a good enantioseparation performance toward aromatic sulfoxides. ${ }^{139}$

\section{LUMINESCENCE PROPERTIES OF MOFS}

Luminescent MOF materials are generally based on active elements such as for example the light-emitting rare earths europium and terbium ${ }^{140,141}$ or on processes stimulated by an organic chromophore that is responsible for both the excitation ${ }^{142,143}$ and the emission process. ${ }^{144,145}$ The MOF luminescence can be tuned through metal and organic ligand substitutions. ${ }^{146}$ The MOF $\left[\mathrm{Ln}_{2} \mathrm{Cl}_{6}(\mathrm{bpy})_{3}\right] .2 \mathrm{bpy}$ has been successfully used for an efficient tuning of the emission colour; this material is interesting as the luminescence is retained also during activation of the MOF for microporous materials. ${ }^{147}$ Different lanthanides can be incorporated into other frameworks such as $\left[\mathrm{Ba}_{2}\left(\mathrm{H}_{2} \mathrm{O}\right)_{4}\left[\mathrm{LnL}_{3}\left(\mathrm{H}_{2} \mathrm{O}\right)_{2}\right]\left(\mathrm{H}_{2} \mathrm{O}\right)_{n} \mathrm{Cl}\right]_{\infty}$ $\left(\mathrm{L} \equiv 4,4^{\prime}\right.$-disulfo-2, $2^{\prime}$-bipyridine- $N, N^{\prime}$-dioxide; $\mathrm{Ln} \equiv \mathrm{Sm}^{3+}$, $\mathrm{Eu}^{3+}$, $\mathrm{Gd}^{3+}, \mathrm{Tb}^{3+}, \mathrm{Dy}^{3+}$ ) (Fig. 7) and the porosity of the MOFs can be tuned by changing the lanthanide ion, maintaining the luminescent properties. ${ }^{148}$

On the other hand a number of MOFs have been prepared containing different chromophores such as trans- $4,4^{\prime}$-stilbene- dicarboxylic acid, which has been observed to increase its rigidity upon coordination, yielding an increase in the emission lifetimes for the MOF system. ${ }^{149}$ It is also possible to assemble fluorescent pentiptycene-base ligands with $\mathrm{Cu}(\mathrm{II})$ ions forming 3D porous MOFs, able not only to selectively adsorb $\mathrm{CO}_{2}, \mathrm{CH}_{4}$ and $\mathrm{N}_{2}$ but also to detect nitroaromatic compounds. ${ }^{150}$

$\mathrm{Cu}(\mathrm{I}) \mathrm{MOFs}$ have been employed as colourimetric detectors for small molecules such as different solvents, halobenzenes, $\mathrm{N}$-heterocycles, amines and nitroaromatic explosives all in the vapour phase (Fig. 8). ${ }^{151}$ Guest molecules in the open channels of MOFs influence the weak interactions between a ligand and a metal centre yielding different luminescence spectra: this effect can be used to tune the emission between ultraviolet and visible wavelengths by controlling the type and number of guest molecules. ${ }^{152}$ Guest - host MOFs containing three different kinds of high-nuclearity metallamacrocycle nanocages have recently been reported. These compounds exhibit yellow-green fluorescence. ${ }^{153}$

\section{SENSING APPLICATIONS OF MOFS}

Luminescent MOFs are potential materials for developing different types of sensors on the basis of their tunable luminescent properties. ${ }^{154,155}$ Some recent results are summarized in a review by Qian and co-workers. ${ }^{156}$ Luminescent MOFs can be utilized in sensory applications for their capability to capture analyte molecules. Luminescent MOFs are employed for example in the detection of volatile organic compounds: $\mathrm{Zn}_{2}$ (tpce) (tpce $\equiv$ tetrakis(4-carboxyphenyl)ethylene), upon exposure to several analytes $\left(\mathrm{NH}_{3}, \mathrm{Et}_{3} \mathrm{~N}, \mathrm{~N}_{2}\right.$, en (三 ethylendiamine), $\mathrm{H}_{2} \mathrm{O}$ ) at room temperature shifts the emission maximum to various extents. ${ }^{157}$ The intensity emission of the lanthanide species $\quad \mathrm{Eu}_{2}(\mathrm{~L})_{3}\left(\mathrm{H}_{2} \mathrm{O}\right)_{4}$.3DMF $\quad\left(\mathrm{L} \equiv 2^{\prime}, 5^{\prime}\right.$-bis(methoxymethyl)$\left[1,1^{\prime}: 4^{\prime}, 1^{\prime \prime}\right.$-terphenyl $]-4,4^{\prime \prime}$-dicarboxylate) was sensibly enhanced upon exposure to solvent vapours of DMF. ${ }^{158}$

A number of luminescent MOFs that can be employed for temperature sensing have been described. The MOF $\mathrm{Zn}_{3}$ (TDPAT)$\left(\mathrm{H}_{2} \mathrm{O}\right)_{3} \quad$ (TDPAT $\equiv 2,4,6$-tris(3,5-dicarboxylphenylamino)-1,3,5triazine) (Fig. 9) exhibits a ligand-centred luminescence around $435 \mathrm{~nm}$ when excited at $370 \mathrm{~nm}$. As the temperature decreases the emission peak position remains unchanged; the intensity on the 


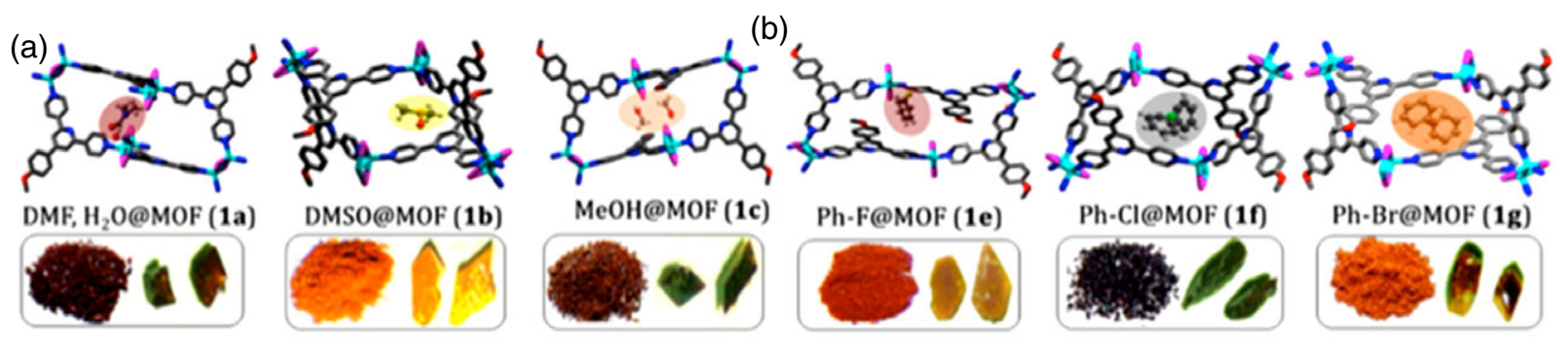

Figure 8. Illustration of guest exchange with visible colour changes in (a) different polar solvent vapours and (b) different monohalobenzene vapours through single crystal to single crystal (SCSC) fashion (reproduced by permission, from ref. 151).

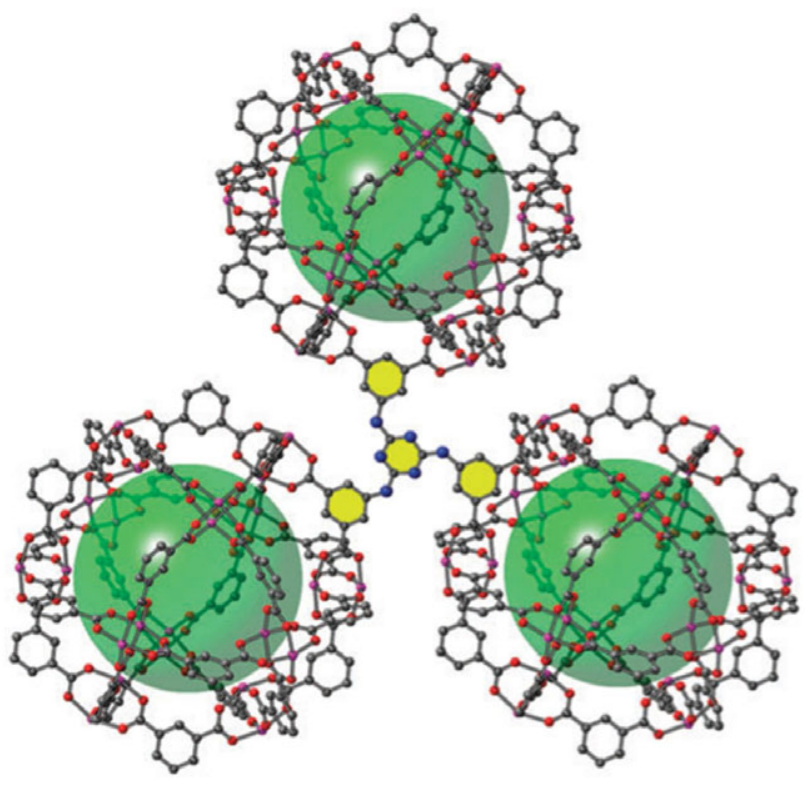

Figure 9. Structure of Zn-TDPAT (Zn purple, C grey, O red, $N$ blue) (reproduced by permission, from ref. 159).

other hand increases due to cooling restrictions of the thermally activated intramolecular rotations and non-radioactive decay. ${ }^{159}$

Tb-dmbdc (dmbdc $\equiv 2,5$-dimethoxy-1,4-benzene dicarboxylate) species also show temperature dependent luminescence behaviour. ${ }^{160}$ Finally MOF sensors can be employed to detect high explosives: the fluorescence of $\mathrm{Zn}_{2}(\mathrm{bpdc})_{2}$ (bpee). 2DMF (bpdc $\equiv 4,4^{\prime}$-biphenyldicarboxylate; bpee $\equiv 1,2$-bis $(4-$ pyridyl)ethylene), exposed to the vapours of 2,4-dinitrotoluene (DNT) (2,4,6-trinitrotoluene (TNT) byproduct), was strongly quenched by more than $80 \%$ within $10 \mathrm{~s}$, as well as being red shifted. ${ }^{161} \quad \mathrm{Eu}_{2}(\mathrm{bdc})_{3}\left(\mathrm{H}_{2} \mathrm{O}\right)_{2} \cdot\left(\mathrm{H}_{2} \mathrm{O}\right)_{2}\left(\mathrm{H}_{2} \mathrm{bdc} \equiv 1\right.$,4-benzene dicarboxylic acid) has also been investigated for the detection of DNT and TNT in ethanol. ${ }^{162}$ Luminescent MOFs have found application as biosensors. MOFs such as MOF- 5 can be tagged with an anti-bovine serum albumin antibody and used for specific sensing of bovine serum albumin. ${ }^{163}$ Post-synthetic methods often allow the addition of pendent additional groups and these structures can be used to tag them with biomolecules. ${ }^{164}$

\section{MOFS FOR WATER, AIR AND FUEL PURIFICATION AND HORTICULTURE}

PCPs and MOFs are very interesting materials for their possible applications to reduce pollution and to remove and eliminate polluting materials from the environment. ${ }^{165}$ The water stress issue, for example, is one of the most relevant problems related to water re-use. Treatment of wastewater to obtain the purity required for differents uses such as culture irrigation is therefore an important key. In addition, in the agricultural sector one of the most important problems is the large use of herbicides and pesticides. ${ }^{166}$ MOFs have recently attracted attention as promising materials for liquid-phase adsorption of hazardous sulfur-containing compounds $(\mathrm{SCCS})^{167}$ and nitrogen-containing compounds (NCCs) ${ }^{168}$ and also as useful adsorbents for oil-removing operations in water purification processes. ${ }^{169}$ The main limitation is generally their high affinity for water, which reduces their ability in cleanup operations. MOFs have been demonstrated to be superior to other porous adsorbents in the removal of SCC and NCC contaminants in petroleum refining and in fuels. ${ }^{170}$ Metal ions such as $\mathrm{Cu}(\mathrm{I}), \mathrm{Ag}(\mathrm{l})$ and $\mathrm{Pd}(\mathrm{II})$ have a very good capability for SCC adsorption due to $\pi$-complex formation. ${ }^{171}$

MOFs based on perylene tetracarboxylic acid ligand and $\mathrm{Ni}$, $\mathrm{Co}, \mathrm{Mn}$ and $\mathrm{Mg}$ metal ions are highly resistant to moisture and exhibit aqueous molecular sieving in the absorption from organic molecule mixtures, their utility being demonstrated in for example the capture of a hazardous water-borne herbicide, Paraquat. ${ }^{172}$ A very stable Zr-based MOF UiO-67 (analogous to UiO-66 and based on $4,4^{\prime}$-biphenyldicarboxylate) has been investigated for adsorption and removal of organophosphorus pesticides from water solutions. It has been found that the abundant $\mathrm{Zr}-\mathrm{OH}$ groups serve as anchorages for the phosphoric groups present in pesticides such as glyphosate and glufosinate. ${ }^{173}$

UiO-66(Zr) displays higher and faster performance with respect to activated carbons in the absorption of methylchlorophenoxy propionic acid, due to the strong electrostatic interaction between sorbent/adsorbate and $p-p$ interaction/stacking with the MOF. ${ }^{174}$ The MOF $\mathrm{Cu}_{2} \mathrm{~L}\left(\mathrm{~L} \equiv 3,3^{\prime}, 5,5^{\prime}\right.$-tetraethyl-4,4'-bipyrazolate), stable in water both in acidic and basic conditions, can be efficiently employed for the removal of trace organic wastes (i.e. toluene, benzene) from contaminated water. ${ }^{175}$ It is worth noting that sometimes a strategy has been used to introduce repellent functional groups in the ligand or in the MOF in order to obstruct water intrusion, enhancing the MOF stability in humid air while maintaining a high sorption capacity toward organic molecules. ${ }^{176} \mathrm{~A}$ recently reported novel MOF with a tetrapodal cage (NKU-101), based on Zn, 4-pyrazolecarboxylic acid and 1,3,5benzenetricarboxylic acid, showed an excellent performance in the adsorption of small very toxic cationic herbicides such as methyl viologen and diquat. ${ }^{177}$ 


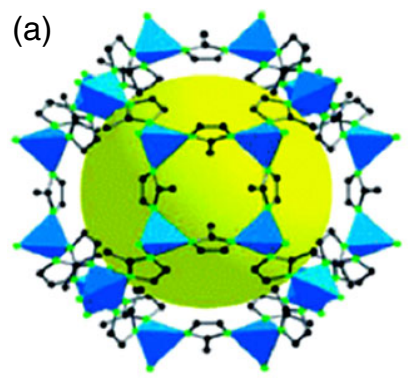

(b)

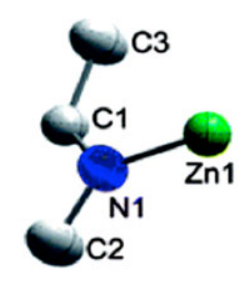

Figure 10. ZIF-8 structure. In (a) the single crystal structure; in (b) ORTEP diagram of the asymmetric unit of ZIF-8 (reproduced by permission, from ref. 180).

An interesting simulation study demonstrated that an ionic rho zeolite-like MOF (ZMOF) can be employed for ion-exchange processes $\left(\mathrm{Na}^{+} / \mathrm{Pb}^{2+}\right)$ and for this reason $Z M O F$ is a suitable candidate for water purification. ${ }^{178}$ MOFs have been employed as green templates to improve the porosity and interconnectivity of porous matrix membranes for water treatment: in particular they have been demonstrated to be useful in the preparation of nanocarbonaceous nanofibre membranes for selective filtration and separation of nanoparticles and in osmotically driven processes. ${ }^{179}$

Zinc-methylimidazolate (ZIF-8) ${ }^{180}$ (Fig. 10) has been demonstrated to be useful for the removal of phthalic acid and diethylphthalate from water solutions, its adsorption capacity being higher than that found for commercial activated carbons. It has been proposed that the absorption is due to electrostatic interaction between ZIF-8 and anionic phthalates or acid - base interactions at low $\mathrm{pH}$ values. ${ }^{181}$ These and some other plausible mechanisms (hydrophobic and $\pi-\pi$ stacking interactions) for the selective adsorption by MOFs and removal of hazardous organic compounds from water have been summarized in a recent review. ${ }^{182}$ ZIF-8 has been employed also for fast adsorption of emerging pollutants such as benzotriazoles from water solutions. ${ }^{183}$ A MOF based on aluminium and fumarate has been investigated for fluoride removal from groundwater. It has been reported that a concentration of $0.75 \mathrm{~g} \mathrm{~L}^{-1}$ of this MOF was efficient for complete removal of $30 \mathrm{mg} \mathrm{L}^{-1}$ fluoride concentration in the feed solution. The replacement of the hydroxyl ions in MOF by fluoride is the dominant mechanism. ${ }^{184}$

MOFs are also potential adsorbents to remove harmful PPCPs (pharmaceuticals and personal care products) from contaminated water. Chromium-benzenedicarboxylate and iron-benzenetricarboxylate (MIL-100-Fe) have been efficiently employed for the adsorptive removal of naproxen and clofibric acid. The adsorption mechanism has been ascribed to a simple electrostatic interaction between PPCPs and the adsorbent. ${ }^{185}$ MIL-100-Fe also shows a high adsorption capacity for the removal of organoarsenic compounds from water. Replacing the central metal ion in the MOF with $\mathrm{Cr}$ and $\mathrm{Al}$ ions produces a lower adsorption capacity: this has been attributed to the facile desorption of $\mathrm{H}_{2} \mathrm{O}$ from MIL-100-Fe and to the large replacement energy shown by MIL-100-Fe. ${ }^{186}$

A novel MOF based on Fe and ethylendiamine has been demonstrated to rapidly extract and pre-concentrate trace amounts of $\mathrm{Cd}(\mathrm{II}), \mathrm{Pb}(\mathrm{II}), \mathrm{Zn}(\mathrm{II})$ and $\mathrm{Cr}(\mathrm{III})$ in agricultural samples. Parameters affecting the pre-concentrations (sorption time, amount of magnetic sorbent, sample $\mathrm{pH}$, type, volume, concentration of the eluent) have also been clearly discussed. Sorption capacity for the four heavy metal ions has been reported. ${ }^{187}$

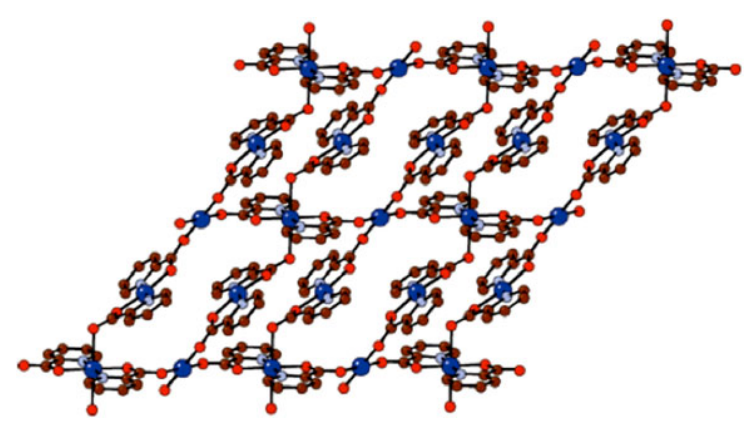

Figure 11. Two-dimensional layer of $\left\{\left[\mathrm{Cu}_{2}(\mathrm{pic})_{3}\left(\mathrm{H}_{2} \mathrm{O}\right)\right] \mathrm{ClO}_{4}\right\}_{n}$ (adapted with permission from Fig. 2 in ref. 193, copyright (2007) American Chemical Society).

\section{MOFS FOR MAGNETIC MATERIALS}

Ordered arrays of magnetically active species constitute an important opportunity for data storage, spin-frustrated catalysis and magnetosensing. Several MOFs and PCPs exhibit specific magnetic and multiferroic properties. For this reason most of the studies in this field are devoted to the design of molecular magnets and low-dimensional magnetic materials. ${ }^{188,189}$

The choice of ligands to produce magnetic frameworks is critical. Several species have been obtained using N-donor heterocycles ${ }^{190}$ with polycarboxylates. ${ }^{191,192}$ However, the closed-shell organic ligands often used in MOFs allow only weak magnetic interactions. Strong coupling between metal centres can be obtained when short oxo, cyano or azido bridges are employed. A weak ferromagnetic coupling has been found in $\left\{\left[\mathrm{Cu}_{2}(\text { pic })_{3}\left(\mathrm{H}_{2} \mathrm{O}\right)\right] \mathrm{ClO}_{4}\right\}_{n}$ (pic $\equiv 2$-picolinate) (Fig. 11) in which chains are linked to one another by syn - anti carboxylate ligands. ${ }^{193}$

Walsh reported a family of ligands (Table 2) suitable for building MOFs with long-range magnetic order between transition metal centres, for which direct quantum chemical calculations suggested Néel temperatures exceeding $100 \mathrm{~K}$ for the case of Mn. ${ }^{194}$ Several MOFs exhibit antiferromagnetic properties as a consequence of antiparallel coupling of the spin metal ions. The hexa-nuclear $\mathrm{Mn}_{2}{ }_{2} \mathrm{Mn}_{4}{ }_{4} \mathrm{O}_{2}$ (pyrazine) ${ }_{2}\left(\mathrm{C}_{6} \mathrm{H}_{5} \mathrm{CH}_{2} \mathrm{COO}\right)_{10}$ having a $3 \mathrm{D}$ porous distorted diamond-like structure shows dominant antiferromagnetic interactions together with a selective $\mathrm{CO}_{2}$ adsorption over $\mathrm{N}_{2}$ and catecholase activity. ${ }^{195}$ The 3D MOF $\left\{\left[\mathrm{Ni}_{3}(\text { ImhedpH })_{2}\left(4,4^{\prime} \text {-bpy) }\right] \cdot 4,4^{\prime} \text {-bpy. } 4 \mathrm{H}_{2} \mathrm{O}\right\}_{n} \quad(\right.$ ImhedpH $\equiv 2-$ (1-imidazole)-1-hydroxyl-1,1'-ethylidenediphosphonate), possessing a (4,4)-connected frl-(42 -64)4(64 - 82) network, showed ferrimagnetism and a field-induced magnetic transition from ferrimagnetism to a fully polarized state. ${ }^{196}$

\section{ELECTROCHEMICAL APPLICATIONS OF MOFS}

MOFs have been studied as anode, cathode and electrolyte materials for lithium ion batteries. $\mathrm{Zn}_{4} \mathrm{O}(\mathrm{BTB})_{2} \cdot(\mathrm{DEF})_{m}\left(\mathrm{H}_{2} \mathrm{O}\right)_{n}$ ( $\mathrm{BTB} \equiv 1$,3,5-benzenetribenzoate; $\quad \mathrm{DEF} \equiv$ diethylformamide) (MOF-177) has been used as an anode material for Li storage. This MOF exhibits a relatively high irreversible capacity in the first discharge process that occurs through a reaction in which the MOF structure is decomposed, with metallic zinc formation: ${ }^{197}$

$$
\mathrm{Zn}_{4} \mathrm{O}(\mathrm{BTB})_{2} \cdot(\mathrm{DEF})_{m}\left(\mathrm{H}_{2} \mathrm{O}\right)_{n}+\mathrm{e}+\mathrm{Li}^{+} \rightarrow \mathrm{Zn}+\mathrm{Li}_{2} \mathrm{O}
$$

$\mathrm{Zn}_{3}(\mathrm{HCOO})_{6}$ is a formate-bridged MOF that can be converted to lithium formate upon lithiation. The reversible conversion reaction drives a notably improved long-term cyclability. ${ }^{198}$ 
Table 2. Selected ligands for building MOFs with long-range magnetic order between transition ions

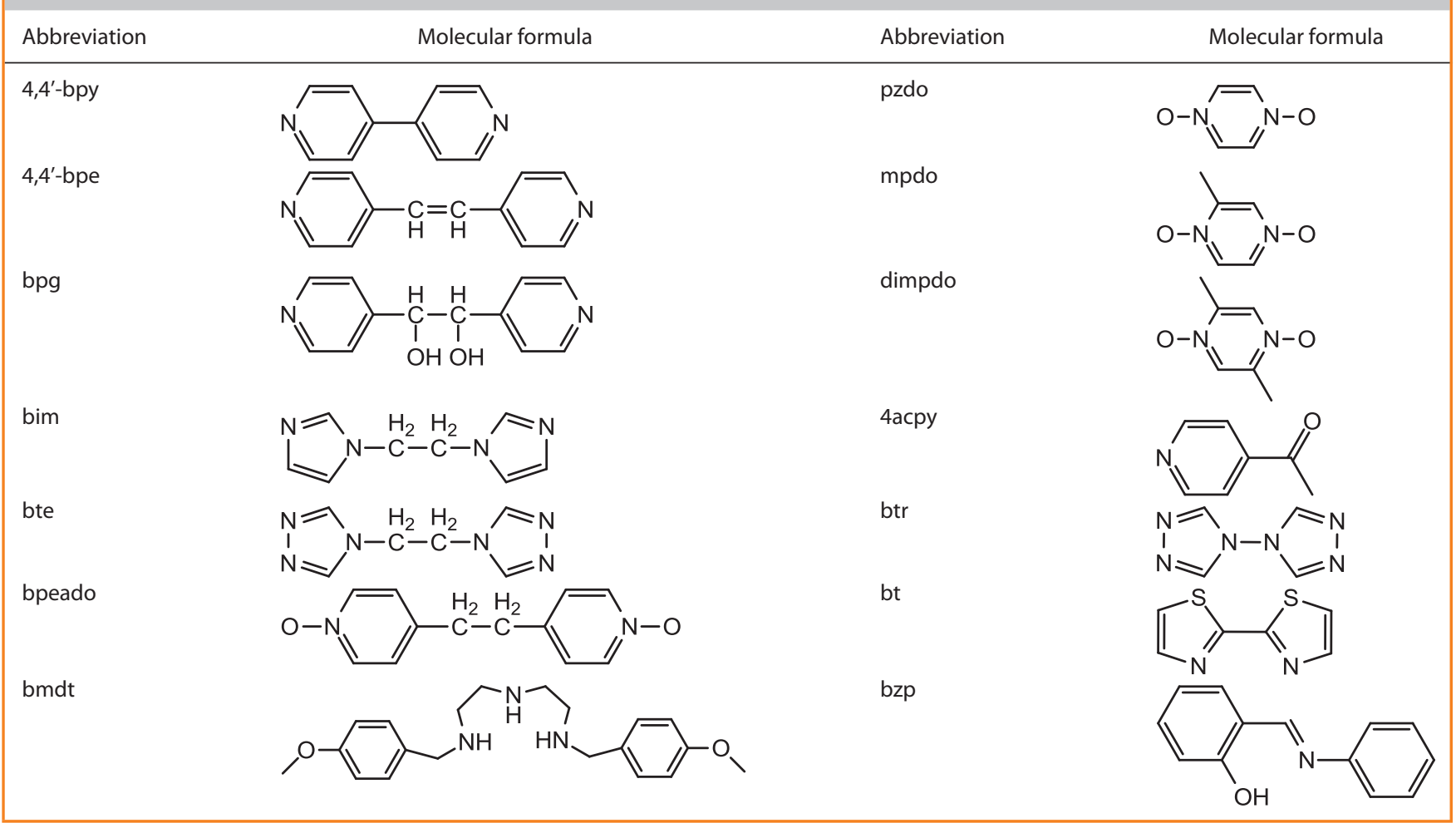

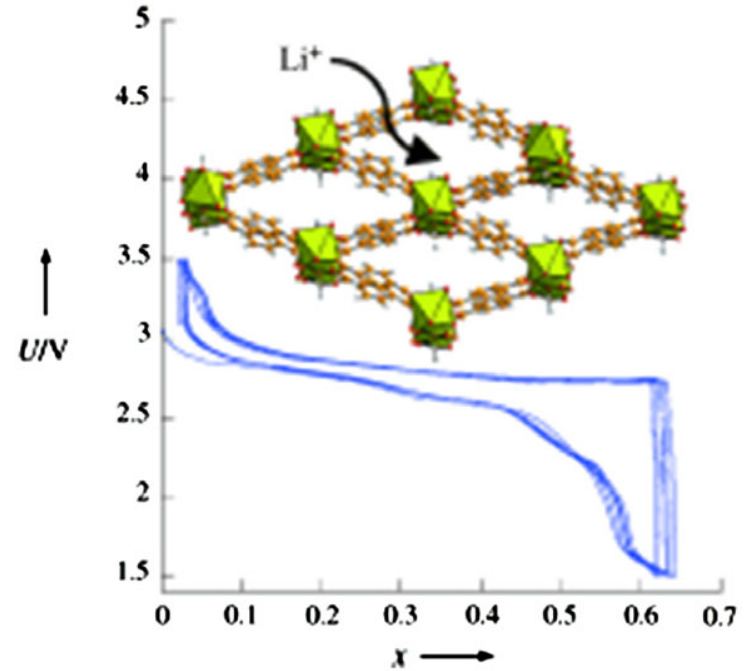

Figure 12. The MIL-53 structure and the voltage profile (reproduced by permission, from ref. 199).

$\mathrm{Fe}^{\mathrm{III}}(\mathrm{OH})_{0.8} \mathrm{~F}_{0.2}\left(\mathrm{O}_{2} \mathrm{CC}_{6} \mathrm{H}_{4} \mathrm{CO}_{2}\right) \quad(\mathrm{MIL}-53(\mathrm{Fe})) \quad($ Fig. 12$)$ has been investigated as rechargeable intercalation cathode material. The reversible capacity of this compound is $70 \mathrm{~mA} \mathrm{~h} \mathrm{~g}^{-1}$ within $1.5-3.5 \mathrm{~V}$ versus $\mathrm{Li}^{+} / \mathrm{Li}^{1}{ }^{199}$

MOF-based supercapacitors have been prepared recently. They can be destroyed to give metal oxides, preserving electrons via charge transfer between the electrolyte and electrode as in the case of hierarchical $\mathrm{Co}_{3} \mathrm{O}_{4}$ structures by heating a Co-based MOF. ${ }^{200}$ It is also possible to pyrolyse MOFs to yield porous carbon, improving the capacity through enhancement of the conductivity. ZIF-8 has been doped with furfuryl alcohol. A first step induced polymerization of the furfuryl alcohol. The second step, a $1000{ }^{\circ} \mathrm{C}$ heat treatment, yielded porous carbon materials achieving a high Brunauer - Emmett - Teller surface area, with a high broad pore size distribution and a specific capacitance of $c a 200 \mathrm{~F} \mathrm{~g}^{-1}$ in acidic aqueous electrolyte. ${ }^{201,202}$

However, one of the first methods was the use of MOFs to store charges through physisorption of electrolyte ions on their internal surfaces. $\mathrm{Zr}_{6} \mathrm{O}_{4}(\mathrm{OH})_{4}(\mathrm{BPYDC})_{6} \quad(\mathrm{BPYDC} \equiv 2$, 2'-bipyridine-5,5'-dicarboxylate) (nMOF-867) was one of the first MOFs used to fabricate electrodes for symmetry coin-type supercapacitor devices and demonstrated high stack and areal performances, preserved over at least 10000 cycles. ${ }^{203}$ MOFs can also be deposited on the surface of an electrode as a coating layer. ZIF-8 has been placed on the surface of Si nanoparticles through ball milling, producing a composite that upon pyrolysis showed high cycling stability and oustanding performances. ${ }^{204}$ MOF-derived mesoporous carbon has found application in lithium selenium batteries. ${ }^{205}$

\section{MOF MEMBRANES}

MOFs can also be employed in industrial applications such as for separation membranes. ${ }^{206}$ Several studies have been published on membranes for gas separation. Several MOF membranes have been prepared to study the permeation of $\mathrm{H}_{2}$. ZIF-8 membranes, for example, are able to separate $\mathrm{H}_{2}$ from larger molecules. ${ }^{207} \mathrm{Co}_{3}(\mathrm{HCOO})_{6}$ shows 1D zigzag channels appropriate for $\mathrm{CO}_{2}$ separation from $\mathrm{CH}_{4}$; in fact the microporous glass-frit supported $\mathrm{CO}_{3}(\mathrm{HCOO})_{6}$ membranes demonstrated a high permeation flux and significant permeation selectivity for $\mathrm{CO}_{2}$ over $\mathrm{CH}_{4}{ }^{208}$ Olefin/paraffin separation is also an emerging issue: the separation of propylene/propane on high-quality ZIF-8 membranes on $\alpha-\mathrm{Al}_{2} \mathrm{O}_{3}$ supports has been investigated; it was 
found that $\mathrm{C}_{3} \mathrm{H}_{8}$ and $\mathrm{C}_{3} \mathrm{H}_{6}$ permeances decreased with increased pressure. The ZIF- 8 membranes showed $\mathrm{C}_{3} \mathrm{H}_{6} / \mathrm{C}_{3} \mathrm{H}_{8}$ selectivity of ca 30 and a relevant $\mathrm{C}_{3} \mathrm{H}_{6}$ permeance. ${ }^{209}$ MOF- 5 based membranes show selective permeation for $\mathrm{CO}_{2}$ over $\mathrm{H}_{2}$ and $\mathrm{N}_{2}$ with respect to $\mathrm{CO}_{2} / \mathrm{H}_{2}$ and $\mathrm{CO}_{2} / \mathrm{N}_{2}$ mixtures. It has been reported that increasing feed pressure yields a sharp increase in separation factor. ${ }^{210}$

\section{CONDUCTIVE MOFS}

MOFs can also exhibit good charge mobility and conductivity. ${ }^{211}$ For example, the introduction of of tetrathiafulvalene into a zinc-based MOF can produce solids with an intrinsic charge mobility of $0.2 \mathrm{~cm}^{2} \mathrm{~V}^{-1} \mathrm{~s}^{-1}$. ${ }^{212}$ The first conductive MOF reported was $\mathrm{Cu}\left[\mathrm{Cu}(\mathrm{pdt})_{2}\right]$ (pdt $\equiv 2,3$-pyrazinedithiolate) which shows an electrical conductivity of $6 \times 10^{-4} \mathrm{~S} \mathrm{~cm}^{-1}$ at $300 \mathrm{~K}^{213}$ A semiconductive $3 \mathrm{D}$ framework $\left\{\left[\mathrm{Cu}^{\prime} \mathrm{Cu}{ }_{2}{ }_{2}(\mathrm{DCTP})_{2}\right] \mathrm{NO}_{3} .1 .5 \mathrm{DMF}\right\}_{n}$ with a narrow band gap of $2.1 \mathrm{eV}$ has recently been reported. Semiconductive behaviour was confirmed by density functional theory calculations. ${ }^{214}$ Thin-film devices of HKUST-1 when infiltrated with redox-active conjugated guest molecules such as 7,7,8,8-tetracyanoquinododimethane possess a tunable, air stable electrical conductivity, with values as high as $7 \mathrm{~S} \mathrm{~m}^{-1} .^{215}$

\section{POLYMER - MOF COMPOSITES}

A recent field of intense investigation is that of MOF-containing composite materials, which span from MOF-metal nanoparticle and MOF-metal oxide composites to MOF-silica and MOF - organic polymer composites, the latter being a research topic relevant for the aims and scope of this journal, but also from MOF - quantum dot and MOF - polyoxometalate composites to MOF - carbon (mainly graphene and carbon nanotube) composites and even MOF - enzyme composites. ${ }^{16,216-222}$ The fabrication of MOF-based composites by using MOFs and other materials can integrate the advantageous features and mitigate the disadvantageous drawbacks of the individual components, thus producing synergistic effects and new functionalities that the individual parts cannot access. ${ }^{2}$

The selectivity and membrane flux of a silicone rubber membrane of polymethylphenylsiloxane (PMPS) has been strongly improved by doping it with ZIF-8 nanoparticles, which create preferential pathways for the permeation of organic compounds. The ZIF-8 nanoparticles, homogeneously embedded in the PMPS matrix, were tested for pervaporation recovery of isobutanol from aqueous $1.0-3.0 \mathrm{wt} \%$ solutions at $80^{\circ} \mathrm{C}$ : the permeance efficiency and separation factor are much higher than those of reported membranes. Moreover, the ZIF-8-PMPS membrane shows higher selectivity in the recovery of other linear bioalcohols (ethanol, $n$-propanol, $n$-butanol and $n$-pentanol) from water compared with the pure PMPS membrane. ${ }^{223}$

Nanocrystals of MOF- 5 have been added to Matrimid ${ }^{\circledR}$ (a commercially available polyimide) to form mixed-matrix membranes for gas separation, and at 30\% MOF-5 loading the permeabilities of the gases tested $\left(\mathrm{N}_{2}, \mathrm{O}_{2}, \mathrm{CH}_{4}, \mathrm{CO}_{2}\right.$ and $\left.\mathrm{H}_{2}\right)$ increased $120 \%$ compared to Matrimid ${ }^{\circledR}$. Additional tests with different mixture ratios showed an increase in selectivity for $\mathrm{CH}_{4}{ }^{224} \mathrm{MIL}-101(\mathrm{Cr})$ has been incorporated in polyethyleneimine affording composites which exhibit considerably enhanced $\mathrm{CO}_{2}$ adsorption capacity at low pressures. Moreover, the resulting adsorbents display rapid adsorption kinetics and ultrahigh selectivity for $\mathrm{CO}_{2}$ over $\mathrm{N}_{2}$ in a flue gas with 0.15 bar $\mathrm{CO}_{2}$ and 0.75 bar $\mathrm{N}_{2}\left(\mathrm{CO}_{2}\right.$ over $\mathrm{N}_{2}$ selectivity is up to 770 at $25^{\circ} \mathrm{C}$ and 1200 at $\left.50^{\circ} \mathrm{C}\right) .{ }^{225}$ HKUST-1-PAM composite beads have been prepared (PAM is a hydrophilic macroporous polyacrylamide) and shown to be an interesting alternative to bulk MOF phases in heterogeneous reaction systems, because the flexibility of the organic component improves the mechanical stability of the crystalline MOF. Moreover, a simple tuning of the reaction concentration can finely modulate the degree of microporosity of the composite. ${ }^{226}$ A novel avenue has recently been opened in the preparation of porous materials from 1D polymers with the report by Cohen and co-workers where a linear, non-porous, mostly amorphous polymer bearing aromatic dicarboxylic groups in the backbone acted as a polymer ligand upon annealing with $\mathrm{Zn}^{2+}$, generating a three-dimensional, porous, crystalline polyMOF hybrid material (polyMOF). ${ }^{227}$

An increasing number of polymerization reactions have been reported to be finely controlled in MOF nanochannels, e.g. the radical polymerization of vinyl monomers into the structure of the porous coordination polymer [Cu(terephthalate) triethylenediamine $\left.{ }_{0.5}\right]_{n}$, where controlled uniaxial alignment of vinyl polymer chains was achieved by host-guest cross-polymerization. ${ }^{228}$ Other polymerization reactions can be efficiently catalysed in functionalized MOFs. ${ }^{3}$ For example, the 1D specific nanochannels of $\left[\mathrm{Cu}_{2}(\mathrm{pzdc})_{2}(\mathrm{~L})\right]_{n}$ (pzdc $\equiv$ pyrazine-2, 3-dicarboxylate; $L \equiv$ pillar ligands), with basic carboxylate oxygen atoms as catalytic interaction sites on the pore walls, accelerate stereo- and monomer-selective polymerization of substituted acetylenes. ${ }^{229}$ The same group of Kitagawa reported the oxidative polymerization of pyrrole within $2 \mathrm{D}$ and 3D MOFs containing redox-active sites, such as $\left[\left\{\mathrm{Ni}(\mathrm{dmen})_{2}\right\}_{2}\left\{\mathrm{Fe}^{\mathrm{III}}(\mathrm{CN})_{6}\right\}\right] \mathrm{PhBSO}_{3}$ (dmen $\equiv 1$,1-dimethylethylenediamine; $\mathrm{PhBSO}_{3} \equiv p$-phenylben zenesulfonate) and $\left[\mathrm{Cu}_{3}(\mathrm{btc})_{2}\right]_{n}$ (btc $\equiv$ benzene-1,3,5-tricarboxy late) respectively, to afford polypyrroles whose orientations are directly related to the original host templates. ${ }^{230,231}$ Photoconductive polysilane, when confined in 1D channels of MOFs such as $[\mathrm{Al}(\mathrm{OH})(\mathrm{L})]_{n} \quad(\mathrm{~L} \equiv 2,6$-naphthalenedicarboxylate or 4,4'-biphenyldicarboxylate), has been found to increase its conductivity because of specific conformational changes. Moreover, the typical photodegradation of polysilane under ultraviolet light is circumvented through the accommodation of polysilane in the nanopores of the MOFs. ${ }^{232}$

Organic polymers can be transformed in antimicrobial materials by adding coordination polymers of silver during the extrusion process. Polyethylene has been loaded with 4,4'-bipyrazolyl-based silver(I) coordination polymers affording composites which display an antibacterial activity against suspensions of Escherichia coli, Pseudomonas aeruginosa and S. aureus, with complete reduction of the three bacterial strains achieved within $24 \mathrm{~h} .{ }^{108}$ Polyethylene has also been loaded with different acylpyrazolone-based coordination polymers of silver(I) affording novel composite materials with potent antimicrobial activity, exerted by a very limited but time persistent release of silver ions with time. The composites, loaded with a very low silver content (1:1000 weight ratio) can be re-used several times, displaying the same antimicrobial activity. The silver additives form agglomerates with dimensions $10-100 \mu \mathrm{m}$ on the polyethylene surface, without changing the elastic and thermal properties of the composites with respect to unloaded polyethylene. Finally, none of the composites is toxic against higher organisms. ${ }^{233,234}$

\section{CONCLUSIONS}

This analysis of more than 200 scientific studies on MOFs demonstrates that these compounds will have again a bright 
future as they repeatedly show ability to respond to the major challenges of the third millennium. This area of chemistry is continuously growing as evidenced by the large number of papers published on the subject. Although many of the studies performed on MOFs still concern the possibility of absorbing in the empty space and releasing hydrogen, carbon dioxide molecules, several ongoing studies are aimed at possible emerging applications, such as drug release, sensing, water purification, air quality management and magnetic materials. To obtain significant results in these areas several drawbacks such as poor selectivity, low capacity and high costs should be overcome as soon as possible.

\section{REFERENCES}

1 Furukawa H, Cordova KE, O’Keeffe M and Yaghi OM, Science 341:974 (2013).

2 Stock N and Biswas S, Chem Rev 112:933 (2012).

3 Yaghi OM, Li H, Eddaoudi N and O'Keeffe M, Nature 402:276 (1999).

4 Férey G, Chem Soc Rev 37:191 (2008).

5 Yaghi OM and Li G, Angew Chem Int Ed 34:207 (1995).

6 Yaghi OM and Li H, J Am Chem Soc 117:10401 (1995).

7 Yaghi OM, O'Keeffe M, Ockwig NW, Chae HK, Eddaoudi M and Kim J, Nature 423:705 (2003)

8 Yaghi OM and Li Q, MRS Bull 34:682 (2009).

9 Fischer RA, Angew Chem Int Ed 53:5716 (2014).

10 Caskey SR and Matzger AJ, Mater Matters 4: 111 (2009).

11 Murray LJ, Dincă M and Long J, Chem Soc Rev 38:1294 (2008).

12 Ferey G and Serre C, Chem Soc Rev 38:1380 (2009).

13 Kuppler RJ, Timmons DJ, Fang QR, Li JR, Makal TA, Younga MD et al., Coord Chem Rev 253:3042 (2009).

14 Janiak C and Vieth JK, New J Chem 34:2366 (2010).

15 Zhang T and Lin W, Chem Soc Rev 43:5982 (2014).

16 Zhu Q-L and Xu Q, Chem Soc Rev 43:5468 (2014).

17 Liu Y, Chen D, Li X, Yu Z, Xia Q, Liang D et al., Green Chem 18:1475 (2016).

18 Liang X, Zhang F, Feng W, Zou X, Zhao C, Na H et al., Chem Sci 4:983 (2013).

19 Panapitiya NP, Wijenayake SN, Huang Y, Bushdiecker D, Nguyen D, Ratanawanate C et al., Polymer 55:2028 (2014).

20 Kitagawa S, Kitaura R and Noro S-i, Angew Chem 116:2388 (2004).

21 Fischer RA, Angew Chem Int Ed 53:5716 (2014).

22 Furukawa H, Go YB, Ko N, Park YK, Uribe-Romo FJ, Kim J et al., Inorg Chem 50:9147 (2011).

23 Li H, Eddaoudi M, O'Keeffe JM and Yaghi OM, Nature 402:276 (1999).

$24 \mathrm{Ni} \mathrm{Z}$ and Masel RI, J Am Chem Soc 128:12394 (2006).

25 Eddaoudi M, Kim J, Rosi N, Vodak D, Wachter J, O'Keeffe JM et al., Science 295:469 (2002).

26 Chui SSY, Lo SMF, Charmant JPH, Orpen AG and Williams ID, Science 283:1149 (1999).

27 Wong-Foy AG, Matzger AJ and Yaghi OM, J Am Chem Soc 128:3494 (2006).

28 Millward AR and Yaghi OM, J Am Chem Soc 127:17998 (2005).

29 Li Y and Yang RT, Langmuir 23:12937 (2007).

30 Choi KM, Park JH and Kang JK, Chem Mater 27:5088 (2015).

31 Schaate A, Roy P, Godt A, Lippke J, Waltz F, Wiebcke M et al., Chem Eur J 17:6643 (2011)

32 Cavka JH, Jakobsen S, Olsbye U, Guillou N, Lamberti C, Bordiga S et al. J Am Chem Soc 130:13850 (2008).

33 Valenzano, L, Civalleri B, Chavan S, Bordiga S, Nilsen MH, Jakobsen S et al., Chem Mater 23:1700 (2011).

34 Furukawa H, Ko N, Go YB, Aratani N, Choi SB, Yazaydin AÖ et al., Science 329:424 (2010).

35 Sim J, Yim H, Ko N, Choi SB, Oh Y, Park HJ et al., Dalton Trans 43:18017 (2014).

36 Serre C, Bourrelly S, Vimont A, Ramsahye NA, Maurin G, Llewellyn PL et al., Adv Mater 19:2246 (2007).

37 Hajjar R, Volkringer C, Loiseau T, Guillou N, Marrot J, Férey G et al., Chem Mater 23:39 (2011).

38 Horcajada P, Salles F, Wuttke S, Devic T, Heurtaux D, Maurin G et al., J Am Chem Soc 133:17839 (2011).

39 Devic T, Wagner V, Guillou N, Vimont A, Haouas M, Pascolini M et al., Microporous Mesoporous Mater 140:25 (2011).
40 Dan-Hardi M, Serre C, Frot T, Rozes L, Maurin G, Sanchez C et al., J Am Chem Soc 131:10857 (2009).

41 Férey G, Science 310:1119 (2005).

42 Férey G, Mellot-Draznieks C, Serre C, Millange F, Dutour J, Surbié S et al., Science 309:2040 (2005).

43 Wickenheisser M, Paul T and Janiak C, Microporous Mesoporous Mater 220:258 (2016)

44 Jeazet HBT, Koshine T, Staudt C, Raetzke K and Janiak C, Membranes 2:331 (2013).

45 Bromberg L, Diao Y, Wu H, Speakman SA and Hatton TA, Chem Mater 24:1664 (2012).

46 Park KS, Ni Z, Côté AP, Choi JY, Huang R, Uribe-Romo FJ et al., Proc Natl Acad Sci USA 103:10186 (2006).

47 Gagnon KJ, Beavers CM and Clearfield A, J Am Chem Soc 135:1252 (2013).

48 Amirjalayer S, Tafipolsky M and Schmid R, J Phys Chem C 115:15133 (2011).

49 Bai N, Li S, Jiang Y, Hu M and Zhai Q, Inorg Chem Commun 53:84 (2015).

50 Jiang HL, Makal TA and Zhou HC, Coord Chem Rev 257:2232 (2013).

51 Odoh SO, Cramer CJ, Truhlar DG and Gagliardi L, Chem Rev 115:6051 (2015).

52 Lim IH, Schrader W and Schüth F, Chem Mater 27:3088 (2015).

53 Parkes MV, Sava Gallis DF, Greathouse JA and Nenoff TM, J Phys Chem C, 119:6556 (2015).

54 Dey C, Kundu T, Biswal BP, Mallick A and Banerjee R Acta Cryst B70:3 (2014).

55 Tranchemontagne DJ, Hunt JR and Yaghi OM, Tetrahedron 64:8553 (2008).

56 Wang C and Ying JY Chem Mater 11:3113 (1999).

57 Sánchez-Sánchez M, Getachew N, Díaz K, Díaz-García M, Chebude Y and Díaz I, Green Chem 17:1500 (2015).

58 Yuan W, Friscis T, Apperley D and James SL, Angew Chem, Int Ed 49:3916 (2010).

59 Klimakow M, Klobes $\mathrm{P}$, Thunemann AF, Rademann $\mathrm{K}$ and Emmerling F, Chem Mater 22:5216 (2010).

60 Friscis T, Halasz I, Beldon PJ, Belenguer AM, Adams F, Kimber SA et al., Nat Chem 5:66 (2013).

61 Friscis T, Reid DC, Halasz I, Stein RS, Dinnebier RE and Duer MJ, Angew Chem Int Ed 49:712 (2009).

62 Jung DW, Yang DA, Kim J and Ahn WS, Dalton Trans 39:2883 (2010).

63 Aslani A and Morsali A, Inorg Chim Acta 362:512 (2009).

$64 \mathrm{Ni} \mathrm{Z}$ and Masel RI, J Am Chem Soc 128:12394 (2006).

65 Hindelang K, Vagin SI, Anger C and Rieger B, Chem Commun 48:2888 (2012).

66 Katz MJ, Brown ZJ, Colón YJ, Siu PW, Scheidt KA, Snurr RQ et al., Chem Commun 49:9449 (2013).

67 Al-Kutubi H, Gascon J, Sudhölter EJR and Rassaei L, ChemElectroChem 2:462 (2015).

68 Martinez Joaristi A, Juan-Alcañiz J, Serra-Crespo P, Kapteijn F and Gascon J, Cryst Growth Des 12:3489 (2012).

69 Falcaro P, Ricco R, Yazdi A, Imaz I, Furukawa S, Maspoch D et al., Coord Chem Rev 307:237 (2016).

70 Röslera C and Fischer RA, CrystEngComm 17:199 (2015).

71 Burrows DA, Metal-organic frameworks: postsynthetic modification, in Encyclopedia of Inorganic and Bioinorganic Chemistry, ed. by Scott RA. John Wiley \& Sons, Oxford, pp. 1-24 (2014).

72 Tuci C, Rossin, A, Xu X, Ranocchiari M, van Bokhoven JA, Luconi L et al. Chem Mater 25:2297 (2013).

73 Suh MP, Park HJ, Prasad TK and Lim DW, Chem Rev 112:782 (2012).

74 Murray L, Dincă M and Long JR, Chem Soc Rev 38:1294 (2009).

75 Dincă M and Long JR, Angew Chem Int Ed 47:6766 (2008).

76 Kitagawa S, Angew Chem Int Ed 54:10696 (2015).

77 Ma S and Zhou HC, Chem Commun 46:44 (2010).

78 Li Y and Yang RT, Langmuir 23:12937 (2007).

79 Han SS, Mendoza-Corte JL and Goddard WA, Chem Soc Rev 38:1460 (2009).

80 Koh K, Wong-Foy A and Matzger A, J Am Chem Soc 131:4184 (2009).

81 Zhao D, Yuan D and Zhou HC, Energy Environ Sci 1:222 (2008).

82 Goldsmith J, Wong-Foy AG, Cafarella MJ and Siegel DJ, Chem Mater 25:3373 (2013).

83 Noro S, Kitagawa S, Kondo M and Seki K, Angew Chem Int Ed 39:2082 (2000).

84 Burd SD, Ma S, Perman JA, Sikora BJ, Snurr RQ, Thallapally PK et al., J Am Chem Soc 134:3663 (2012). 
85 Peng Y, Krungleviciute V, Eryazici I, Hupp JT, Farha OK and Yildirim T, J Am Chem Soc 135:11887 (2013).

86 Alezi D, Belmabkhout Y, Suyetin M, Bhatt PM, Weselinski LJ, Solovyeva $V$ et al., J Am Chem Soc 137:13308 (2015).

87 Peng X, Cheng X and Cao D, J Mater Chem 21:11259 (2011).

88 McGuire CV and Forgan RS, Chem Commun 51:5199 (2015).

89 Janiak C and Vieth JK, New J Chem 34:2366 (2010).

90 Tabacaru J, Pettinari C, Timokhin I, Marchetti F, Carrasco Marin F, Maldonado-Hodar FJ et al., Cryst Growth Des 13:3087 (2013).

91 Baima J, Macchieraldo R, Pettinari C and Casassa S, CrystEngComm 17:448 (2015).

92 Fernandez M and Barnard AS, ACS Comb Sci 18:243 (2016).

93 Keskin S and Kizilel S, Ind Eng Chem Res 50:1799 (2011).

94 Horcajada P, Serre C, Maurin G, Ramsahye NA, Balas F, Vallet-Regi M et al., J Am Chem Soc 130:6774 (2008).

95 Koh K, Wong-Foy AG and Matzger AJ, Angew Chem Int Ed 47:677 (2008).

96 Babarao R and Jiang JW, J Phys Chem C 113:18287 (2009).

97 An J, Geib SJ and Rosi NL, J Am Chem Soc 131:8376 (2009).

98 Huxford RC, Della Rocca J and Lin W, Curr Op Chem Biol 14:262 (2010).

99 McKinlay AC, Morris RE, Horcajada P, Ferey G, Gref R, Couvreur P et al., Angew Chem Int Ed 49:6260 (2010).

100 Morris W, Briley WE, Auyeung E, Cabezas MD and Mirkin CA, J Am Chem Soc 136:7261 (2014).

101 Horcajada P, Chalati T, Serre C, Gillet B, Sebrie C, Baati T et al., Nat Mater 9:172 (2010).

102 Cunha D, Yahia MB, Hall S, Miller SR, Chevreau H, Elkaim E et al., Chem Mater 25:2767 (2013).

103 Rieter JW, Pott KM, Taylor KML and Lin WB, J Am Chem Soc 130:11584 (2008).

104 Taylor-Pashow KM, Della Rocca J, Xie Z, Tran S and Lin W, J Am Chem Soc 131:14261 (2009).

105 Xiao B, Wheatley PS, Zhao XB, Fletcher AJ, Fox S, Rossi AG et al., J Am Chem Soc 129:1203 (2007).

106 Nguyenn JG, Tanabe KK and Cohen SM, CrystEngComm 12:2335 (2010).

107 Rieter WJ, Taylor KML and Lin WB, J Am Chem Soc 128:9024 (2006).

108 Tabacaru A, Pettinari C, Marchetti F, Di Nicola C, Domasevitch KV, Galli S et al., Inorg Chem 51:9775 (2012).

109 Agostoni V, Horcajada P, Noiray M, Malanga M, Aykac A, Jicsinszky L et al., Sci Rep 5:7925 (2015).

110 Li W, Zhang Y, Xu Z, Meng Q, Fan Z, Ye S et al., Angew Chem Int Ed 55:955 (2016).

111 Liu J, Chen L, Cui H, Zhang J, Zhang L and Su C-Y, Chem Soc Rev 43:6011 (2014).

112 Kitagawa S, Kitaura R and Noro S, Angew Chem Int Ed 43:2334 (2004).

113 Gascon J, Corma A, Kapteijn F and Llabrés i Xamena FX, ACS Catal 4:361 (2014).

114 Chugtai AH, Ahmad N, Younus HA, Laypkov A and Verpoort F, Chem Soc Rev 44:6804 (2015).

115 Llabrés i Xamena FX, Casanova O, Galiasso Tailleur R, Garcia H and Corma A, J Catal 255:220 (2008).

116 Pramanik A, Abbina S and Das G, Polyhedron 26:5225 (2007).

117 Fujita M, Kwon YJ, Washizu S and Ogura K, J Am Chem Soc 116:1151 (1994).

118 Horcajada P, Surble S, Serre C, Hong DY, Seo YK, Chang JS et al., Chem Commun 2820 (2007).

119 Miralda CM, Macias EE, Zhu M, Ratnasamy P and Carreon MA, ACS Catal 2:180 (2012).

120 Vermoortele F, Bueken B, Le Bars G, Van de Voorde B, Vandichel M, Houthoofd K et al., J Am Chem Soc 135:11465 (2013).

121 Tonigold M, Lu Y, Mavrandonakis A, Puls A, Staudt R, Mollmer J et al., Chem Eur J 17:8671 (2011).

122 Jing X, He C, Dong D, Yang L and Duan C, Angew Chem Int Ed 51:10127 (2012).

123 Henschel A, Gedrich K, Kraehnert R and Kaskel S, Chem Commun 4192 (2008).

124 Alaerts L, Seguin E, Poelman H, Thibault-Starzyk F, Jacobs PA and De Vos DE, Chem Eur J 12:7353 (2006).

125 Ravon U, Domine ME, Gaudillere C, Desmartin-Chomel A and Farruseng D, New J Chem 32:937 (2008).

126 Luz I, León A, Boronat M, Llabrés i Xamena FX and Corma A, Catal Sci Technol 3:371 (2013).

127 Ngyen LT, Ngyen TT, Nguyen KD and Phan NT, Appl Catal A 425:44 (2012).

128 Pan Y, Yuan B, Li Y and He D, Chem Commun 46:2280 (2010).
129 Phan NT, Le KK and Phan DT, Appl Catal A 382:246 (2010).

130 Phan A, Czaja AU, Gándara F, Knobler CB and Yaghi OM, Inorg Chem 50:7388 (2011).

131 Timokhin I, Pettinari C, Marchetti F, Pettinari R, Condello F, Galli S et al., Cryst Growth Des 15:2303 (2015).

132 Gándara F, Gornez-Lor B, Gutiérrez-Puebla E, Iglesias M, Monge MA, Proserpio DM et al., Chem Mater 20:72 (2008).

133 Timofeeva MN, Panchenko VN, Jun JW, Hasan Z, Matrosova MM and Jhung SH, Appl Catal A 471:91 (2014).

134 Wu CD and Lin WB, Angew Chem Int Ed Engl 46:1075 (2007).

135 Wang Z, Tanabe KK and Cohen SM, Inorg Chem 48:296 (2009).

136 Saito M, Toyao T, Ueda K, Kamegawa T, Horiuchi Y and Matsuoka M, Dalton Trans 42:9444 (2013).

137 Beyzavi MH, Stephenson CJ, Liu Y, Karagiaridi O, Hupp JT and Farha OK, Front Energ Res 2:63 (2015).

138 Saedi Z, Safarifard V and Morsali A, Microporous Mesoporous Mater 229:51 (2016).

139 Zhang J, Li Z, Gong W, Han X, Liu Y and Cui Y, Inorg Chem 55:7229 (2016).

140 Binnemans K, Chem Rev 109:4283 (2009).

141 Cui Y, Yue Y, Qian G and Chen B, Chem Rev 112:1126 (2012).

142 Eremenko A, Smirnova N, Rusina O, Linnik O, Eremenko TB, Spanhel L et al., J Mol Struct 553:1 (2000).

143 Ravilious CF, Farrara RT and Liebson SH, J Opt Soc Am 44:238 (1954).

144 Habib HA, Sanchiz J and Janiak C, Dalton Trans 1734 (2008).

145 Wang MS, Guo SP, Li Y, Cai LZ, Zou JP, Xu G et al., J Am Chem Soc 131:13572 (2009).

146 Sava Gallis DF, Rohwer LE, Rodriguez MA and Nenoff TM, Chem Mater 26:2943 (2014).

147 Matthes PR, Höller CJ, Mai M, Heck J, Sedlmaier SJ, Schmiechen S et al., J Mater Chem 22:10179 (2012).

148 Chandler BD, Cramb DT and Shimidzu GKH, J Am Chem Soc 128:10403 (2006).

149 Bauer CA, Timofeeva TV, Settersten TB, Patterson BD, Liu VH, Simmons BA et al., J Am Chem Soc 129:7136 (2007).

150 Zhang M, Zhang L, Xiao Z, Zhang Q, Wang R, Dai F et al., Sci Rep 6:20672 (2016).

151 Khatua S, Goswami S, Biswas S, Tomar K, Jean HS and Konar S, Chem Mater 27:5349 (2015).

152 Huang YQ, de Andres A, Gomez-Lor B, Gutiérrez-Puebla E, Iglesias M, Monge MA et al., Cryst Growth Des 8:378 (2008).

153 Fang ZL, Wu XY, Yu RM and Lu CZ CrystEngComm 16:8769 (2014).

154 Cui Y, Zhu F, Chen B and Qian G, Chem Commun 51:7420 (2015).

155 Hu Z, Deibert BJ and Li J, Chem Soc Rev 43:5815 (2014).

156 Zhao D, Cui Y, Yang Yu and Qian G, CrystEngComm 18:3746 (2016).

157 Shustova NB, McCarthy BD and Dincă M, J Am Chem Soc 133:20126 (2011).

158 Li Y, Zhang S and Song D, Angew Chem Int Ed 52:710 (2013).

159 Ma D, Li B, Zhou X, Zhou Q, Liu K, Zeng G et al., Chem Commun 49:8964 (2013).

160 D'Vries RF, Alvarez-Garcia S, Snejko N, Bausa LE, Gutierrez-Puebla E, de Andres A et al., J Mater Chem C 1:6316 (2013).

161 Lan A, Li K, Wu H, Olson DH, Emge TJ, Ki W et al., Angew Chem Int Ed 48:2334 (2009).

162 Xu H, Liu F, Cui Y, Chen B and Qian G, Chem Commun 47:3153 (2011).

163 Bharadwaj LM, J Porous Mater 43:114 (2014).

164 Kumar P, Deep A and Kim KH, Trends Analyt Chem 73:39 (2015).

165 Khan NA, Hasan Z and Jhung SH, J Hazard Mater 244-245:444 (2013).

166 Hedegaard MJ, Arvin E, Corfitzen CB and Albrechtsen HJ, Sci Total Environ 499:257 (2014).

167 Khan NA and Jhung SH, J Hazard Mater 260:1050 (2013).

168 Ahmed I, Khan NA and Jhung SH, Inorg Chem 52:14155 (2013).

169 de Voordde BV, Bueken B, Denayer J and De Vos D, Chem Soc Rev 43:5766 (2014).

170 Cychosz KA, Wong-Foy AG and Matzger AJ, J Am Chem Soc 131:6938 (2008).

171 Yang RT, Hernandez-Maldonado AJ and Yang FH, Science 301:79 (2003).

172 Majumder M, Sheath P, Mardel Jl, Harvey TG, Thornton AW, Gonzago A et al., Chem Mater 24:4647 (2012).

173 Zhu X, Li B, Yang J, Li Y, Zhao W, Shi J et al., ACS Appl Mater Interfaces 7:223 (2015).

174 Seo YS, Khan NA and Jhung SH, Chem Eng J 270:22 (2015).

175 Wang JH, Li M and Li D, Chem Eur J 20:12004 (2014).

176 Wu T, Shen L, Luebbers M, Hu C, Chen Q, Ni Z et al., Chem Commun 46:6120 (2010). 
177 Jia YY, Zhang YH, Xu J, Feng R, Zhang MS and Bu XH, Chem Commun 51:17439 (2015).

178 Nalaparaju A and Jiang J, J Phys Chem C 116:6925 (2012).

179 Lee JY, Tang CY and Huo F, Sci Rep 4:3470 (2014).

180 Isimjan TT, Kazemian H, Rohani S and Ray AK, J Mater Chem 20:10241 (2010).

181 Khan NA, Jung BK, Hasan Z and Jhung SH, J Hazard Mater 282:194 (2015).

182 Hasan Z and Jhung SH, J Hazard Mater 283:329 (2015).

183 Jiang JQ, Yang CX and Yan XP, ACS Appl Mater Interfaces 5:9837 (2013).

184 Karmakar S, Dechnik J, Janiak C and De S, J Hazard Mater 303:10 (2016).

185 Hasan Z, Jeon J and Jhung SH, J Hazard Mater 209-210:151 (2012).

186 Jun JW, Tong M, Jung BK, Hasan Z, Zhing C and Jhung SH, Chem Eur J 21:347 (2015).

187 Babazadeh M, Hosseinzadeh-Khanmiri R, Abolhasani J, Ghorbani-Kalhor E and Hassanpour A, RSC Adv 5:19884 (2015).

188 Kurmoo M, Chem Soc Rev 38:1353 (2009).

189 Miller JS, Dalton Trans 2742 (2006).

190 Murray KS, Eur J Inorg Chem 3101 (2008).

191 Kurmoo M, Kumagai H, Hughes SM and Kepert CJ, Inorg Chem 42:6709 (2003).

192 Guillou N, Livage C and Frey G, Eur J Inorg Chem 4963 (2006).

193 Biswas C, Mukherjee P, Drew MGB, Gomez-Garcia CJ, Clemente-Juan JM and Ghosh A, Inorg Chem 46:10771 (2007).

194 Tiana D, Hendon CH and Walsh A, Chem Commun 50:13990 (2014).

195 Kar P, Haldar R, Gómez-García CJ and Ghosh A, Inorg Chem 51:4265 (2012).

196 Wu XQ, Han ML, Xu GW, Liu B, Li DS and Zhang J, Inorg Chem Commun 58:60 (2015)

197 Li XX, Cheng FY, Zhang SN and Chen J, J Power Sources 160:542 (2006).

198 Saravanan K, Nagarathinam M, Balaya P and Vittal JJ, J Mater Chem 20:8329 (2010)

199 Ferey G, Millange F, Morcrette N, Serre C, Doublet ML, Greneche JM et al., Angew Chem Int Ed 46:3259 (2007).

200 Zhang F, Hao L, Zhang LJ and Zhang XG, Int J Electrochem Sci 6:2943 (2011).

201 Jiang HL, Liu B, Lan YQ, Kuratani K, Akita T, Shioyama H et al., J Am Chem Soc 133:11854 (2011).

202 Chaikittisilp W, Hu M, Wang H, Huang HS, Fujita T, Wu KCW et al., Chem Commun 48:7259 (2012).

203 Liu XW, Sun TJ, Hu JL and Wang S-D, J Mater Chem 4:3584 (2016)

204 Han Y, Qi P, Feng X, Li S, Fu X, Li H et al., ACS Appl Mater Interfaces 7:2178 (2015).

205 Lai YQ, Gan YQ, Zhang ZA, Chen W and Li J, Electrochim Acta 146:134 (2014).
206 Qiu S, Xue M and Zhu G, Chem Soc Rev 43:6116 (2014).

207 Bux H, Liang F, Li Y, Cravillon J, Wiebcke M and Caro J, J Am Chem Soc 131:16000 (2009).

208 Zou X, Zhang F, Thomas S, Zhu G, Valtchev V and Mintova S, Chem Eur J 17:12076 (2011).

209 Liu D, Ma X, Xi H and Lin YS, J Membr Sci 451:85 (2014).

210 Zhao Z, Ma X, Kasik A, Li Z and Lin YS, Ind Eng Chem Res 52:1102 (2013).

211 Sun L, Campbell MG and Dincă M, Angew Chem Int Ed 55:3566 (2016).

212 Narayan TC, Miyakai T and Dincă M, J Am Chem Soc 134:12932 (2012).

213 Takaishi S, Hosoda M, Kajiwara T, Miyasaka H, Yamashita M, Nakanishi $Y$ et al., Inorg Chem 48:9048 (2009).

214 Wu ZL, Wang CH, Zhao B, Dong J, Lu F, Wang WH et al., Angew Chem Int Ed 55:4938 (2016)

215 Talin AA, Centrone A, Ford AC, Foster ME, Stavila V, Haney P et al., Science 343:66 (2014).

216 Liu X-W, Sun T-J, Hu J-L and Wang S-D, J Mater Chem A 4:3584 (2016).

217 Bradshaw D, Garai A and Huo J, Chem Soc Rev 41:2344 (2012).

218 Moon HR, Lim DW and Suh MP, Chem Soc Rev 42:1807 (2013).

219 Ahmed I and Jhung SH, Mater Today 17:136 (2014).

220 Yao J and Wang H, Chem Soc Rev 43:4470 (2014).

221 Lei J, Qian R, Ling P, Cui L and Ju H, Trends Analyt Chem 58:71 (2014).

222 Li S and Huo F, Nanoscale 7:7482 (2015).

223 Liu X-L, Li Y-S, Zhu G-Q, Ban Y-J, Xu L-Y and Yang W-S, Angew Chem Int Ed 50:10636 (2011).

224 Perez EV, Balkus KJ Jr, Ferraris JP and Musselman IH, J Membr Sci 328:165 (2009).

225 Lin Y, Yan Q, Kong C and Chen L, Sci Rep 3:1859 (2013).

226 O'Neill LD, Zhang H and Bradshaw D, J Mater Chem 20:5720 (2010).

227 Zhang Z, Nguyen HTH, Miller SA and Cohen SM, Angew Chem Int Ed 54:6152 (2015).

228 Distefano G, Suzuki H, Tsujimoto M, Isoda S, Bracco S, Comotti A et al., Nature Chem 5:335 (2013).

229 Uemura T, Kitaura R, Ohta Y, Nagaoka M and Kitagawa S, Angew Chem Int Ed 45:4112 (2006)

230 Yanai N, Uemura T, Ohba M, Kadowaki Y, Maesato M, Takenaka M et al., Angew Chem Int Ed 47:9883 (2008).

231 Uemura T, Kadowaki Y, Yanai N and Kitagawa S, Chem Mater 21:4096 (2009).

232 Kitao T, Bracco S, Comotti A, Sozzani P, Naito M, Seki S et al., J Am Chem Soc 137:5231 (2015).

233 Marchetti F, Palmucci J, Pettinari C, Pettinari R, Condello F, Ferraro S et al., Chem Eur J 21:836 (2015).

234 Marchetti F, Palmucci J, Pettinari C, Pettinari R, Marangoni M, Ferraro S et al., ACS Appl Mater Interfaces 8:29676 (2016). 